\title{
White space interpretation in Hermann Rorschach's inkblot test: An analysis of two male examinees' responses
}

\author{
Interpretacje białego tła w teście Hermanna Rorschacha - analiza wypowiedzi dwu mężczyzn
}

\author{
Anna Hunca-BednarskaABCDEF,
}

MONAR Center, Lublin

\begin{abstract}
Introduction: There are numerous points of controversy over the psychological interpretation of the so-called S responses namely, the interpretation of white space in the Rorschach test. The aim of my paper was to verify the position held by Charles $\mathrm{P}$. Fonda, who claims that the meaning of $\mathrm{S}$ responses depends on the results of the test as a whole.

Materials and methods: I have presented the responses of two young men and coded them according to the Comprehensive System developed by John E. Exner. I chose this way of processing data as the most precise, relatively well formalized, and detailed one. The two examinees gave an almost identical number of responses in the whole test and a similar number of $\mathrm{S}$ responses, similarly distributed across the cards of the test.

Results: I assessed and compared the results of the two examinees in terms of the effectiveness of their cognitive processes, selfcontrol ability, mental resources, social adjustment, and self-esteem. Finally, I looked closely at the contents of a few responses, as in my opinion they symbolically expressed the examinees' basic problems.

Discussion: I tried to avoid describing the examinees' psyche in nosological terms and to focus on presenting the way in which they experienced the world, as well as on how this experience affected their behavior.

Conclusions: I found that in Examinee 1 criticism towards other people may stem from an excessively idealistic attitude to the world and from the ensuing disappointments. Good cognitive functioning, resistance to stress, positive self-esteem, and the socialized emotional sphere make this man's S responses a sign of creative engagement in the problems encountered rather than a sign of maladjustment. In the case of Examinee 2, S responses can be understood as defiance and a generalized attitude of negativism, which play the role of defense against the excessively complicated, not fully comprehensible, and inhospitable world; these responses may, in their turn, contribute to the intensification of problems and to an increase in maladjustment.
\end{abstract}

Keywords: Rorschach inkblot test, $\mathrm{S}$ responses (space responses), emotional control, cognitive processes, social adjustment

\section{Streszczenie}

Wstęp: Wskazałam na liczne kontrowersje dotyczące psychologicznej interpretacji tzw. wypowiedzi S, czyli interpretowania białego tła w teście Rorschacha. Jako cel artykułu przyjęłam weryfikację stanowiska Charlsa P. Fondy, który twierdzi, że znaczenie wypowiedzi S zależy od wyników testu ujętych w całości.

Materiał i metoda: Przedstawiłam wypowiedzi dwu młodych mężczyzn i zasygnowałam je według Systemu Całościowego opracowanego przez Johna E. Exnera ( The Comprehensive System). Wybrałam ten sposób opracowania danych, ponieważ w mojej opinii, jest on najprecyzyjniejszy, stosunkowo dobrze sformalizowany i szczegółowy. Obaj badani podali niemal identyczną liczbę wy powiedzi w całym badaniu oraz zbliżoną liczbę wypowiedzi S, których rozkład był podobny pod względem kolejności pojawiania się na poszczególne tablice testu.

Wyniki: Oceniłam i porównałam wyniki obu badanych pod względem efektywności ich procesów poznawczych, zdolności do samokontroli, zasobów psychicznych, przystosowania społecznego i samooceny. W końcu zatrzymałam się na treści kilku wypowiedzi podanych przez badanych, ponieważ w mojej opinii wyrażały one, w symbolicznej formie ich podstawowe problemy.

Dyskusja: Starałam się uniknąć opisu psychiki w terminach nozologicznych a skoncentrować się na przedstawieniu, w jaki sposób doświadczają oni świata i jak doświadczenie to wpływa na ich zachowania. 
Wnioski: Wykazałam, że u badanego nr 1 krytycyzm żywiony do innych ludzi a wyrażany w wypowiedziach S może wynikać ze zbyt idealistycznej postawy do świata i związanych z tym rozczarowań. Dobre funkcjonowanie poznawcze, odporność na stres, pozytywna samoocena i uspołeczniona sfera emocjonalna sprawiają, że wypowiedzi S u tego mężczyzny świadczą raczej o twórczym zaangażowaniu w napotykane problemy niż o nieprzystosowaniu. W przypadku badanego nr 2 wypowiedzi S można rozumieć jako bunt i zgeneralizowaną postawę negatywizmu, które pełnią rolę obrony przed zbyt skomplikowanym, niezupełnie zrozumiałym i nieprzychylnym światem; reakcje te z kolei mogą przyczyniać się do nasilenia psychologicznych problemów i nieprzystosowania.

Słowa kluczowe: Rorschacha, wypowiedzi S (space responses), kontrola emocji, procesy poznawcze, przystosowanie społeczne

\section{Introduction}

The aim of the present article is to show how human experience of the world is reflected in the interpretation of inkblots. I will do it through the lens of so-called $\mathrm{S}$ responses. Interpreting the white background rather than the inkblots visible against it is a behavior that can be treated as a reaction contrary to the instruction; in the Rorschach test the examinee is asked to see something in the inkblot presented, which amounts to a suggestion that it is the inkblots that are to be the object of interest. If the examinee turns his or her attention to the white background, this kind of response can be construed as showing an attitude of negation, defiance, or even aggression. This attitude may stem from the examinee's personality traits, or it may be a reaction to the examination situation. This understanding of the phenomenon discussed here is very often found in the literature; there is also a considerable body of empirical data supporting this position. Other opinions are not rare, however. Researchers point out that, regardless of the related tendency to tinge responses with aggression, white space interpretation is associated with striving for autonomy and independence and with an original and creative approach to the task. Charles P. Fonda even mentions the striving to achieve some degree of mastery in controlling and changing the environment, indicated by psychoanalytically-oriented psychologists; this striving is associated with the maturity and complexity of the psyche and is a source of satisfaction [1]. Interpretations of the white background are called $\mathrm{S}$ responses (space responses); I will refer to the individuals who often give $\mathrm{S}$ responses as "S examinees". I have discussed the issues related to interpreting white space elsewhere [2]. It should be noted that many psychological meanings, frequently opposing ones, are attributed to S responses. Moreover, among $\mathrm{S}$ examinees there are not only strong, selfconfident, and assertive individuals but also the ones who are psychologically weak and who are desperately and compensatorily struggling to maintain their independence and autonomy. The latter are mentioned by Zygmunt Piotrowski, a scholar whom I consider one of the most insightful in discussing the meanings of $\mathrm{S}$ responses and the most emphatic in stressing their ambiguity. Piotrowski points out that compensatory reactions in the form of $S$ responses may be associated with the inability to make any changes, as this usually exceeds the psychological capabilities of this kind of person [3]. I believe it is legitimate to try to understand such cases as an attitude of opposition against oneself. John E. Exner links S responses above all with negativism, aggression, and hostility. These emotional states may manifest themselves explicitly, in external behavior, but they may also be suppressed and restricted to internal tensions. Exner notes that, in both cases, the result are difficulties in maintaining satisfying relations with other people and an inability to cope with life's current problems [4]. According to this author, what is also important is the sequence of $\mathrm{S}$ responses. When they are given to the first three cards of the test, they are mainly reactive and may stem either from a negative attitude to the test situation itself or from a more stable characteristic, associated with some problems associated with the relationship to authority. If S responses are given to further cards of the test, it is rather the subject's stable dispositions (trait-like features) that should be considered [4]. According to Exner, all researchers stress that if a person generates many $\mathrm{S}$ responses, this may mean certain tensions and conflicts that impinge on the person's contact with reality [4]. Piotrowski's opinion is similar - when it becomes a basic need and is undertaken even in situations in which there is no pressure from the environment, the struggle to maintain one's autonomy may become a kind of maladjustment or even attest to mental states akin to delusions. An examinee who gives more S responses may feel that other people do not accept his or her reactions and attitudes, which separates this person from the social environment and may become a source of conflicts [3].

A practicing psychologist is, therefore, faced with a considerable challenge when interpreting $S$ responses in the case of a specific examinee. What is immensely helpful in this situation, is one of the main interpretative principles in the Rorschach test, which is that the meaning of nearly every score acquires a certain specificity when considered against the backdrop of a given person's results in the whole test. For instance, Piotrowski follows Rorschach in observing that what is significant for the interpretation of $\mathrm{S}$ are responses determined by color 
alone or by the predominance of color over shape (form). Responding to color alone is associated with suggestibility and impulsiveness. The greater the predominance of color over form and over responses determined by human movement, the greater the likelihood that $\mathrm{S}$ will manifest itself in external opposition, disobedience, quarrelsomeness, and provocative behavior. And the other way around: with good emotional control and adequate socialization (which is supposed to be indicated in the inkblot test by a predominance of the form determinant over the color determinant in formulating responses), an increased number of $\mathrm{S}$ will raise the likelihood of positive traits, such as creative assertiveness, energy, and originality of thought, and critical attitude towards others may have a constructive character. Even in that case, however, one should take into account that the examinees may be experiencing dissatisfaction in coping with life's problems and with themselves, which may lead to a sense of frustration and, consequently, to a higher level of aggression as a secondary outcome $[4,5]$.

As can be seen, examinees with an increased number of S responses may significantly differ from one another. This group may include not only those who have come into conflict with the law, but also those who represent the right hierarchy of values; it will also often include weak people who are not prone to changes and people with a great potential of energy and a good prognosis in psychotherapy. I believe it is worth appreciating the intuition voiced by Piotrowski, who drew attention to the link of white space with depressiveness. In such cases, examinees frequently see white spaces as representing void or emptiness, which can be interpreted symbolically [3].

To sum up, let me quote Fonda's view, similar to Piotrowski's: "It is not unreasonable, of course, to assume that $\mathrm{S}$ may be related to adaptive behaviour in emotionally mature individuals and to maladaptive behaviour in the disturbed" [1, s. 143].

In this article I will compare the responses given by two men examined with the Rorschach test. The comparison concerns the interpretations that can be attributed to $\mathrm{S}$ responses in these two cases. I leave aside the data concerning the examinees themselves as persons and provide only the information about their sex and age (Examinee 1 was 30 years old and Examinee 2 was 20). I do so because I wish to investigate only $\mathrm{S}$ responses in the context of the whole test; this is not a study of two cases. I treat the responses obtained as a kind of autonomous whole or text, and until the final conclusions I prefer to leave the information about the examinees aside, as what is important for me is to show the power of the meanings hidden in inkblot interpretations.

\section{Material and method}

The testing procedure as well as the coding and interpreting of responses was based on the system developed by Exner (i.e., the Comprehensive System). The decision to choose this system was dictated by the fact that it provides what I consider to be the most exhaustive evaluation of examinees' responses. In this system, the first step in the analysis consists in coding the responses in the order in which they were given (Exner refers the outcome of this procedure as the Sequence of Scores). I will, therefore, provide all the responses generated by the tested men, both those given in the actual examination phase and some of those that were added during what can be called the Inquiry Phase, and then, I will present the codes of these responses. When assessing how well the responses fitted the presented stimuli I used the examples given in the respective tables of Exner's 2003 manual. I have decided not to present the results of the next stage of data processing (a higher level of analysis), the outcome of which is structural data (Exner uses the term Structural Summary) [4, 5], comprising various groupings of codes, numeric scores, and the values of numerous indices and indicators. The decision not to present the Structural Summary (which is part of the author's documentation) was dictated by practical considerations. Explaining all the data included in the Structural Summary would not always directly concern $\mathrm{S}$ responses and would necessitate expanding the present article beyond an unacceptable size. I will, therefore, select only the most relevant elements from the Structural Summary. Generally speaking, these will be mainly those features of responses that should be associated with the effectiveness and originality of cognitive processes, the emotional sphere, and social adjustment.

I selected two male examinees whose reports contained a roughly equal total number of responses. Many researchers stress the significance of the total number of responses given in the whole test because it may be significant when interpreting the number of responses representing specific categories. Considering the character of the responses given by the two examinees, one can generally say that, at first glance, there were no dramatic differences between them; a more detailed analysis, however, revealed considerable problems in the case of one of examinee. This is consistent with my intention, which was for differences associated with the meanings of $\mathrm{S}$ responses to manifest themselves as clearly as possible.

Examinee 1 (30 responses) interpreted white space five times and Examinee 2 - seven times. I think that although this difference is not entirely without importance, both examinees can be classified in this respect as belonging to the same category. Exner believes 
that if there is no $\mathrm{S}$ response or if there are two such responses, this may be regarded as a not particularly significant situation. If there are three $S$ responses and if they concern the first two cards, it is legitimate to speak about a negativistic attitude towards the test itself. If four or five S responses were given and if they concern the first three cards, it can be concluded that the examinee was irritated by the test situation. This does not have to be associated with a stable personality trait, but it should be taken into account that the examinee may react with negativism and defiance when confronted with unwanted challenges or when experiencing problems in his or her relationship to authority. Exner points out that two cases are significant for the interpretation of test results. The first case is a situation when there are three $\mathrm{S}$ responses and one of them concerns a card further in the sequence than Card II. This attests to the examinee being more oppositional than most people. This oppositional quality does not have to be a burden for the person's functioning, but it may disturb the harmony of his or her social relations. The second case is the occurrence of four or more $\mathrm{S}$ responses, with at least one of them concerning a card further in the sequence than Card III. In this kind of situation, it can be suspected that the examinee's level of negative emotions (anger) is decidedly above average and impacts the person's functioning, decision making, and coping in relations with other people. This way of responding is a relatively stable trait-like feature rather than an expression of the examinee's negative attitude towards the test as such. Both men selected for the analysis represent this particular kind of case. The distributions of their $\mathrm{S}$ responses are fairly equal across all ten cards of the test (Examinee 1: II, IV, VII, X; Examinee 2: II, III, VII, X).

Here are the responses given by Examinee 1 (in parentheses I provide those explanations from the Inquiry Phase that I consider important).

I

1. a moth (it is moth-shaped and unevenly gray, as moths typically are)

2. a part of the human skeleton (shaded bones and their arrangement can be seen)

3. two bird heads, a mirror image (you can see their plumage and uneven coloration)

4. a beetle (it simply looks like a beetle)

II

5. two elephants dancing

6. a plane in flight

7. < little rabbits (they seem to be running)

8. $\quad v$ an explosion, some kind of burst (you can see it go off, and the red color, those red splashes show it too)

9. a pussy cat (well, here it is, the eyes and ears)
10. two people (doing something)

11. a red butterfly (it is butterfly-shaped)

IV

12. a kind of crab, something like that

13. a camel's head

14. bird heads (the shape of a head and a beak)

15. a person seen from a worm's eye view (you get this kind of shape when photographing from below, that's all)

$\mathrm{V}$

16. a butterfly in flight

17. a bat in flight

VI

18. something like a star on a mast

19. reflections of faces

VII

20. a head wearing a helmet

21. the face of some kind of monster (an animal, the outlines of its eyes are visible through the shading, this was important)

VIII

22. two predators walking (the pink color, it helped me see them too)

23. a mountain (gray, just like in pictures, sort of pink)

24. the thyroid (tinged with colors, it has a shape of the thyroid)

25. some kind of arrow

IX

26. some two green monsters roaring symmetrically

27. a head and a part of the trunk, an alien's maybe

$\mathrm{X}$

28. The face of some kind of odd creature, eyes, eyebrows, astonishment, confusion (I speak about an odd creature because of the colors]

29. a castle on top of a hill

30. plankton (plankton-like colors and shapes)

The numbers showing the order of responses may be followed by $>$ or $\mathrm{v}$, which indicates a lateral or inverted position of the card, respectively. The most important responses generated in the Inquiry Phase are provided in parentheses. As it is illustrated in Table 1 in the first column there are scores coding the areas of the inkblot that were interpreted and the type of location. W means the interpretation of the whole inkblot; D stands for the interpretation of a large and well-defined blot; Dd stands for the interpretation of a small or less well-defined portion of the inkblot. S indicates white space interpretation. White space may be combined with the whole inkblot (WS) or with a part of it (DS, DdS), but even if white space alone is used, it is indicated in Exner's system whether the area commented on is large (WS, DS) or small (DdS). In the 
Table 1. Sequence of scores

\begin{tabular}{|c|c|c|c|c|c|c|c|}
\hline Card & $\begin{array}{c}\text { Response } \\
\text { No. }\end{array}$ & $\begin{array}{c}\text { Area and } \\
\text { Location } \\
\text { Type }\end{array}$ & $\begin{array}{l}\text { Determinant } \\
\text { and Form } \\
\text { Quality }\end{array}$ & Contents & $\begin{array}{l}\text { Popular } \\
\text { Responses }\end{array}$ & Z-Score & $\begin{array}{l}\text { Special } \\
\text { Scores }\end{array}$ \\
\hline \multirow[t]{4}{*}{ I } & 1. & Wo & FYo & A & & 1.0 & \\
\hline & 2. & Wo & YF- & An & & 1.0 & \\
\hline & 3. & $\mathrm{D}+$ & YF.Fr.o (2) & $\mathrm{Ad}$ & & 6.0 & \\
\hline & 4. & Do & Fo & A & & & \\
\hline \multirow[t]{5}{*}{ II } & 5. & $\mathrm{D}+$ & $\mathrm{M}^{\mathrm{a}} \mathrm{O}(2)$ & A & $\mathrm{P}$ & 3.0 & \\
\hline & 6. & DSo & $\mathrm{m}^{\mathrm{a}} \mathbf{O}$ & Sc & & & \\
\hline & 7. & Do & $\mathrm{FM}^{\mathrm{a}} \mathrm{O}$ & A & & & \\
\hline & 8. & Do & $\mathrm{m}^{\mathrm{a}}$.FCo & Ex & & & \\
\hline & 9. & DdSo & $\mathrm{Fu}$ & A & & 4.5 & \\
\hline \multirow[t]{2}{*}{ III } & 10. & D+ & $\mathrm{M}^{\mathrm{a}} \mathrm{o}(2)$ & $\mathrm{H}$ & $\mathrm{P}$ & 3.0 & GHR \\
\hline & 11. & Do & FCo & $\mathrm{Ad}$ & & & \\
\hline \multirow[t]{4}{*}{ IV } & 12. & Wo & F- & A & & 1.0 & \\
\hline & 13. & Do & $\mathrm{Fu}$ & $\mathrm{Ad}$ & & & \\
\hline & 14. & DSo & Fo & $\mathrm{Ad}$ & & 5.0 & \\
\hline & 15. & Wo & FDo & $\mathrm{H}$ & $\mathrm{P}$ & 2.0 & \\
\hline \multirow[t]{2}{*}{$\mathrm{V}$} & 16. & Wo & $\mathrm{FM}^{\mathrm{a}} \mathrm{O}$ & A & $\mathrm{P}$ & 1.0 & \\
\hline & 17. & Wo & $\mathrm{FM}^{\mathrm{a}} \mathrm{O}$ & A & $\mathrm{P}$ & 1.0 & PSV \\
\hline \multirow[t]{2}{*}{ VI } & 18. & $\mathrm{~W}+$ & F- & Sc & & 2.5 & INCOM1 \\
\hline & 19. & $\mathrm{D}+$ & Fru & $\mathrm{Hd}$ & & 2.5 & PHR \\
\hline \multirow[t]{2}{*}{ VII } & 20. & DS+ & $\mathrm{Fu}$ & $\mathrm{Hd}, \mathrm{Cg}$ & & & PHR \\
\hline & 21. & Do & YFo & $\mathrm{Ad}$ & & & DV1 \\
\hline \multirow[t]{4}{*}{ VIII } & 22. & Do & FMa.FCo (2) & A & $\mathrm{P}$ & & \\
\hline & 23. & Do & CFo & Ls & & & \\
\hline & 24 & Do & CF- & An & & & \\
\hline & 25 & Ddo & F- & Sc & & & \\
\hline \multirow[t]{2}{*}{ IX } & 26 & $\mathrm{D}+$ & 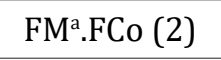 & A & & & DV1 \\
\hline & 27 & Do & $\mathrm{Fu}$ & (Hd) & & & GHR \\
\hline \multirow[t]{3}{*}{$\mathrm{X}$} & 28 & DSo & $\mathrm{M}^{\mathrm{a}} \cdot \mathrm{FC}-$ & $\mathrm{Hd}$ & & 6.0 & PHR \\
\hline & 29 & DS+ & $\mathrm{FCu}$ & Sc, Ls & & 6.0 & \\
\hline & 30 & Do & $\mathrm{FCu}$ & A & & & \\
\hline
\end{tabular}

above example there are two types of location: ordinary location (o), which is scored when the examinee can see a single object with a specific form demand, and synthesized location (+), which is scored when the response concerns two objects perceived as separate but related to each other and when at least one of these objects is determined by the form of the inkblot. Location type is also referred to as Developmental Quality (DQ). DQ is the estimated degree to which inkblot structure was used in the response. In the presented protocol there are two types of location: +, when the examinee perceived separate objects linked by some kind of meaningful relationship, and o, which stands for "ordinary," when the examinee perceived one object with a specific form demand.

The second column contains response determinants and the level of fit between the examinee's observation and the stimulus if the $\mathrm{F}$ determinant was used. F indicates being guided by the form of the inkblot, C stands for 
using color, FC means being guided mainly by color while simultaneously taking form into account as well. Y stands for using diffuse shading in responses and may occur in combinations analogous to those involving the form and color determinants. FD indicates the perception of perspective (a spatial quality) determined by the form and size of inkblots. (2) is the code for responses about pairs of objects, while Fr is the code for reflection responses. M stands for human movement responses, FM indicates animal movement responses, and $\mathrm{m}$ is the code for inanimate movement responses. A small letter a indicates active movement (as opposed to passive movement, coded as a small letter $\mathrm{p}$ ). In the presented study there were three scores of form quality: $o$ is an ordinary response; $u$ is an unusual response, one that requires some effort to see what the examinee can see in the inkblot; - indicates a response that does not fit the inkblot.

The content of responses is coded in the third column. $\mathrm{H}$ is a whole human figure, $\mathrm{Hd}$ is a human detail, $(\mathrm{Hd})$ is a human detail that is a part of a fictional or fantasy figure. A is an animal and Ad is an animal detail. Sc is the code for objects associated with the achievements of science or craft, An is anatomy, Ex is explosion, Cg is clothing, and Ls stands for landscape. $\mathrm{P}$ indicates which response is a popular one and is followed by a numerical $\mathrm{Z}$ score, given for the degree of organizational activity involved in the response. There are four types of responses that can be coded for a $\mathrm{Z}$ score: a response interpreting the whole inkblot (with synthesized or ordinary location); a response using adjacent details as related to each other; a response using interrelated but nonadjacent details; and a response integrating white space with some inkblot area (responses of the last kind are usually scored the highest). A Z score can be determined only for those responses that use the form of the inkblot. The last column is so-called special scores, which indicate various kinds of abnormalities and additional features of responses. In the cases analyzed here these are mainly GHR and PHR. These are codes for responses concerning a human figure (Good Human Representational Response and Poor Human Representational Response, respectively). Due to a certain complexity of the criteria for classifying specific responses as GHR or PHR, rather than discuss the criteria here, I refer the reader to the guidelines provided by Exner [4]. Generally, it can be said that the preferred perception is that of a whole human figure in the context of positive emotional coloring. Also promoted is good form quality, which involves the fit of the response with the stimulus and the lack of serious abnormalities in the response (this refers particularly to some of the special scores). In the case of Examinee 1 there were three GHR scores and three PHR scores. DV (which stands for deviant verbalization) indicates mainly surprising or inappropriate words used in the response. In the case of Examinee 1 these were subtle and commonly found abnormalities or errors (e.g., the word "face" used with reference to an animal and the somewhat odd reference to monsters' roaring as performed symmetrically). Both DV scores represent the first, less pathological level, indicated by the number 1 . There was also one inappropriate combination (INCOM), also assessed as belonging to level 1 . Another special score is PSV, meaning perseveration. It is used when the examinee repeats the same content (as in the case in Examinee 2) or when there are responses very close to one another in terms of content and with the same scores for the same card (in the case of Examinee 1 these are responses to Card V).

The fifth response to Card II is noteworthy. It concerns elephants, which means its content are animals. But these animals are engaging in an activity typical of humans (there is no explanation that they are, for example, elephants in a circus), which means this response is determined by human movement.

And here are the responses given by Examinee 2. I

1. a bat (the wings here, the trunk there)

2. some kind of butterfly (has wings like a bat, etc.)

3. some kind of insect (likewise)

II

4. some face, an animal's, a person's (the examiner's question: an animal's or a person's?) both (?) more likely a human face

5. some kind of spaceship, a vehicle

6. some kind of island, rocks, a lagoon (the lagoon is here and the rocks are further away, in the background -?- they are smaller)

III

7. people, doing something, washing something in a river (in the grey blot at the bottom I see the "lip-like" shapes as waves against a shining surface)

8. sort of animal face

9. a vase

IV

10. this is a tree (the shape of a tree, and the shades simply make it look as if there is a kind of foliage)

11. some big fellow, a guy, a big one, a giant

12. a spaceship

$\mathrm{V}$

13. this must be a bat

14. some kind of bird perhaps

15. it all looks very much like a space vehicle

VI

16. a space vehicle, even more like it here

17. some kind of animal (as if lying, with its legs 
Table 2. Sequence of scores

\begin{tabular}{|c|c|c|c|c|c|c|c|}
\hline Card & $\begin{array}{c}\text { Response } \\
\text { No. }\end{array}$ & $\begin{array}{l}\text { Area and } \\
\text { Location } \\
\text { Type }\end{array}$ & $\begin{array}{l}\text { Determinant } \\
\text { and Form } \\
\text { Quality }\end{array}$ & Contents & $\begin{array}{l}\text { Popular } \\
\text { Responses }\end{array}$ & Z-Score & $\begin{array}{l}\text { Special } \\
\text { Scores }\end{array}$ \\
\hline \multirow[t]{3}{*}{ I } & 1. & Wo & Fo & A & $\mathrm{P}$ & 1.0 & \\
\hline & 2. & Wo & Fo & A & $\mathrm{P}$ & 1.0 & PSV \\
\hline & 3. & Wo & F- & A & & 1.0 & \\
\hline \multirow[t]{3}{*}{ II } & 4. & WSo & F- & $\mathrm{Hd}$ & & 4.5 & PHR \\
\hline & 5. & Wo & F- & Sc & & 4.5 & \\
\hline & 6. & $\mathrm{Wv}$ & FDu & $-\mathrm{Na}$ & & 4.5 & \\
\hline \multirow[t]{3}{*}{ III } & 7. & $\mathrm{D}+$ & $M^{a} \cdot m^{p} . Y o$ & $\mathrm{H},-\mathrm{Na}$ & $\mathrm{P}$ & 3.0 & GHR \\
\hline & 8. & DSo & F- & $\mathrm{Ad}$ & & 4.5 & DV1 \\
\hline & 9. & Ddo & F- & Art & & & \\
\hline \multirow[t]{3}{*}{ IV } & 10. & Wo & FYo & $\mathrm{Bt}$ & $\mathrm{P}$ & 2.0 & \\
\hline & 11. & Ddo & Fo & $\mathrm{H}$ & & & GHR \\
\hline & 12. & Wo & $\mathrm{Fu}$ & Sc & & 2.0 & PSV \\
\hline \multirow[t]{3}{*}{ V } & 13. & Wo & Fo & A & $\mathrm{P}$ & 1.0 & \\
\hline & 14. & Wo & Fo & A & & 1.0 & PSV \\
\hline & 15. & Wo & $\mathrm{Fu}$ & Sc & & 2.5 & PSV \\
\hline \multirow[t]{3}{*}{ VI } & 16. & Wo & $\mathrm{Fu}$ & Sc & & 2.5 & \\
\hline & 17. & Wo & $\mathrm{FM}^{\mathrm{p}} \mathrm{O}$ & A & & 2.5 & \\
\hline & 18. & Wo & $\mathrm{Fu}$ & Ay & & 2.5 & \\
\hline \multirow[t]{3}{*}{ VII } & 19. & DSv & $\mathrm{Fu}$ & $\mathrm{Na}$ & & & \\
\hline & 20. & Do & F- & $\mathrm{Hd}$ & & & PHR \\
\hline & 21. & WSo & F- & (Hd) & & 4.5 & GHR \\
\hline \multirow[t]{4}{*}{ VIII } & 22. & $\mathrm{~W}+$ & $\mathrm{FM}^{\mathrm{a}} \mathrm{O} .(2)$ & A, & $\mathrm{P}$ & 3.0 & \\
\hline & 23. & Dd+ & F- & Sc, Ls & & & \\
\hline & 24 & Wo & $\mathrm{Fu}$ & Art & & 4.5 & \\
\hline & 25 & Wo & $\mathrm{Fu}$ & Sc & & 4.5 & PSV \\
\hline \multirow[t]{3}{*}{ IX } & 26 & Ddo & $\mathrm{FCu}$ & (Hd) & & & GHR \\
\hline & 27 & $\mathrm{~W}+$ & FC.FDu & $\mathrm{Hh}, \mathrm{Bt}$ & & 5.5 & \\
\hline & 28 & Do & FCo & $\mathrm{Bt}$ & & & \\
\hline \multirow[t]{3}{*}{$\mathrm{X}$} & 29 & DdS+ & FC.FDu & $\mathrm{Sc},-\mathrm{Na}$ & & 6.0 & \\
\hline & 30 & WS+ & Formless $M^{a}$.FC- & $\mathrm{H}, \mathrm{Sc}$ & & 5.5 & COP, PHR \\
\hline & 31 & $\mathrm{~W}+$ & Ma- & $\mathrm{H}, \mathrm{Sc}$ & & & PHR \\
\hline
\end{tabular}

here, thrown apart, and its whiskers here)

18. a club

VII

19. this looks like some kind of lake

20. there seem to be hands there (four of them, hands with thumbs)

21. some kind of mask (for covering the face)
VIII

22. some two animals, climbing up

23. some kind of cottage (the yellowish part of the orange inkblot is rocks, the pink part is the base of the cottage)

24. some kind of cup, also

25. some kind of space vehicle 
IX

26. the face of some kind of monster (from the movie Hellboy) (?) (he was a king of the forest, he grew from a grain, so colors have to be here too)

27. some kind of basket with fruit in it (the fruits are closer, the basket is in the background, colors must also be considered because of the fruits)

28. flowers (flowers have their shape, but they are colorful, too!)

$\mathrm{X}$

29. some kind of pond, and next to the pond there is an entrance to some building or tunnel, the tunnel is far and small, so the pink and gray colors are appropriate

30. a castle hall, some kind of party, a general impression of people dancing, the pink is the stairs, the colors are helpful

31. a church, people in pews on the sides, the altar, people walking in the center

As it is illustrated in Table2, in the case of Examinee 2 , several new codes have appeared; for instance formless $\mathrm{M}$ is a score applied when the response is determined by human movement but the sense of movement consists in a general impression, not associated with any particular form. In the Contents column, the following scores have appeared: $\mathrm{Na}$, which indicates natural phenomena; $\mathrm{Bt}$, which is used for plants; Art, which indicates contents associated with art; Hh, introduced to code householdrelated objects; and, finally, Ay, associated with anthropological contents. If $\mathrm{Na}$ appears in the contents, the examiner should ignore other contents involved in computing the Isolation Index, such as Bt and Ls. In the Special Scores column, a COP code appeared. It is attributed to those responses that are about cooperation or positive relationship between two or more objects (I see the ballroom party mentioned in response 30 as presupposing some kind of cooperation of people with one another and positive relations among them). Responses 6 and 19 have been coded $\mathrm{Wv}$, which stands for vague location and is used when the examinee interprets the inkblot as something with a vague shape, when shape is irrelevant to the perceived object, and when it is something that may change. Responses of this kind do not require the structuring of the stimulus; they usually remain general impressions.

As I have mentioned before, when comparing the results obtained from the two examinees, I use those elements of the Structural Summary that I consider relevant to the interpretation of $\mathrm{S}$ responses.

\section{Results}

The most important element in the assessment of cognitive functioning is the fit (or congruity) of responses with the inkblots presented. The percentage of incongruous (minus) responses was $20 \%$ (for Examinee 1) and $29 \%$ (for Examinee 2). This figure is higher than what is usually found in the case of healthy individuals. I believe, however, that in these two cases the high percentage of incongruous responses reflects a casual attitude to the test and no intention to "distinguish oneself at all costs" rather than a lack of intelligence. To some extent, this interpretation is supported by the fact that neither of the examinees generated responses with very good form quality, distinguished by high precision and detail in the description of the perceived shape. Responses of this kind attest not only to a good intellect but frequently also to high motivation to do as well as possible in the test. Likewise, what may attest to a desire to impress is an increased number of all responses, but in the case of the two examinees this number did not exceed the average values. I assume that the critical value for the percentage of "minus" responses is 29 , because this number is a limit for the Rorschach Perceptual-Thinking Index (PTI); a value higher than 29 testifies to some kind of abnormality. Still, it must be said that in Examinee 2 cognitive processes were significantly "worse" than in Examinee 1 and need explanation.

The two men also differed considerably in the number of ordinary form quality responses (o) (17 for the first examinee and 10 for the second one). The low number of these responses in the case of Examinee 2 was associated with a high number of unusual form quality responses (42\% of all responses in the whole test). Unusual responses (u) are responses that fit the presented stimuli but do not impose themselves as obvious; above all, they are much less often given by examinees. These responses cannot be said to directly attest to worse cognitive functioning, but they definitely indicate either that their author does not reckon with the consequences or that his thoughts follow less popular paths - either way, it can be expected that the examinee's responses may not always be fully comprehensible and socially acceptable. Exner reports that the percentage of unusual responses does not usually exceed 25, and a percentage higher than 30 is a serious problem [4]. This means that in the case of Examinee 2 the percentage of unusual responses was definitely very high. The percentage of ordinary form quality responses is at the same time the percentage of $\mathrm{X}+$ responses, which is the sum of ordinary and superioroverelaborated responses (I observed no responses of the latter kind in either of the two examinees).

The next important indicator of the effectiveness of cognitive processes is the percentage of $\mathrm{S}-$ responses (computed in relation to all minus responses). In the case of Examinee 1, this percentage was 17, while in the case 
of Examinee 2 it was as high as 36. Exner adopts 33\% of $\mathrm{S}-$ as the limit [6]. If the examinee has generated more than $33 \%$ of such responses, this may indicate negativism or anger strong enough to disturb cognitive functioning. Empirical studies show that increased $\mathrm{S}-$ percentages occur particularly often in young people and tend not to be associated with psychoticism. Exner, however, strongly links percentages of minus $\mathrm{S}$ responses higher than 33 with the need for intervention, especially when the overall number of minus responses is higher than three [6], and this kind of result is the case in Examinee 2.

Generally, it can be said that in Examinee 2 cognitive processes may be prone to disorganization as a result of negative emotions (anger); additionally, being unconventional, they may not fit the generally accepted conventions. Such conclusions cannot be drawn with regard to Examinee 1; what is more, in Piotrowski's interpretation system, his response 9 should be classified as original. It seems that, despite the minus response 28 , this examinee's $\mathrm{S}$ responses can usually be said to fit the stimuli; sometimes they are even brilliant and may be a sign of independent and creative thinking. Returning to Examinee 2, it should be noted, finally, that the numerous cases of perseveration in his responses attest to the rigidity of behavior and thinking (in Examinee 1 perseveration occurred only once, while in Examinee 2 it occurred six times).

To sum up the data discussed so far, it should be said that, apart from often not fitting the stimuli, the thoughts of Examinee 2 frequently followed a less socially common paths (though the number of responses popular in terms of content was practically the same in the two examinees), which means his mental harmony with the social environment may not have been sufficient; moreover, his thought processes were easily disorganized as a result of negative emotions, and reactions of anger, defiance, and criticism, when they did occur, may have been inappropriate to the situation and maladaptive. Mental maladjustment increases the rigidity of cognitive processes (numerous perseverations).

In order to fully characterize the cognitive functioning of both examinees, it is necessary to make further steps. Firstly, it is necessary to count those interpretations of inkblots in which the examinees were guided by more than one determinant when formulating a single response (Blends). In the case of the first examinee there were six of them and in the case of the second one there were five, so there are no significant differences to be found here; both examinees used the complexity of the stimuli presented to them to a similar degree (i.e., they took into account not only the shape of the inkblots but also their other features, such as colors or movement). Secondly, the sum score for $\mathrm{Z}$ responses should be computed and compared with the estimated values predicted for the frequency of these responses. The $\Sigma \mathrm{Z}$ value was lower for the first examinee (45.5) and, importantly, it was lower than expected, though only slightly so. The second examinee had a higher $\Sigma \mathrm{Z}$ score (72.0), which means he spent more energy on organizing the stimulus field, but the results of his effort were not fully effective either, as $\sum \mathrm{Z}$ was lower than expected [4]. Thirdly, attention should be paid to Developmental Quality (DQ). There was a difference in this respect: although both examinees had valuable scores, DQo and DQ+, Examinee 2 gave two responses that were coded as v. What this attests to is that Examinee 2 sometimes stopped at a general impression and did not analyze the structure of the inkblot.

My next conclusion is that in both examinees, particularly in Examinee 2, cognitive processes were not fully effective in relation to the effort made. Moreover, Examinee 2 sometimes did not use inkblot structure in his interpretations, which may show that he simplified the task he was asked to do.

In order to assess self-control ability, it is necessary to consider the psychological resources that are easily accessible and that a person can use in everyday functioning. It is assumed that what shows this potential in the Rorschach test is the number of human movement responses and the number of responses determined by (chromatic) color. The examinee's score for such responses is coded as EA (Experience Actual) [4, 5]. It is believed that average EA values (for adults and adolescents) range from 7 to 11 [4]. Examinee 1 scored 7.5 and Examinee 2 scored 5.5. This means neither score is high, but whereas that of Examinee 1 is within the normal range, that of Examinee 2 is too low. Exner believes that individuals with low EA are subject to permanent disorganization as a result of ordinary stresses inherent in everyday life and are more easily hurt. These people function better in situations that are well structured and unambiguous. Taking the Rorschach test, in which one is supposed to interpret vague inkblots, must have been highly stressful for the second examinee.

Perhaps this is why Examinee 2 adopted an attitude of avoidance, ignoring the complexity of the stimuli presented to him. This attitude (i.e., the avoidant style) is verified in the Rorschach test by checking if the examinee uses mainly the shape of inkblots while ignoring their other features, such as color or shading. This attitude is expressed as L (Lambda). Lambda is the ratio of responses determined by inkblot form alone to all the remaining responses. $\mathrm{L}$ is usually lower than 1 . Its value for the first examinee was 0.43 . If $\mathrm{L}$ is higher than 1 , and especially if it is higher than 1.2, it is legitimate to speak of a very strong tendency to simplify. For the second examinee the value of L was 1.8, which is very high. Following Exner's detailed 
guidelines [4], it is reasonable to suspect that Examinee 2 maintains this attitude also in life situations other than psychological examination. The avoidant style can be treated as an effort aimed at controlling the complex situations encountered in life in the simplest possible way, in a manner that is economical and negates the complex nature of stimuli. Sometimes such an indirect form of control may be effective and may free a person from the sense of being overwhelmed by the external situation. However, the avoidant tendency may be ineffective when it stands in conflict with the need to take into account the complexity of a given situation. Michał Stasiakiewicz writes that a high value of the $L$ index combined with a low percentage of good form quality responses (X+\%) and with a low number of popular responses may testify to an individualistic and not particularly empathic way of functioning and a tendency to engage in confrontational behaviors [5]. In Examinee 2 the percentage of $\mathrm{X}_{+}$ responses (32) was not high, but the average number of popular responses (5, according to Polish standards) was sufficient [7]. Generally speaking, however, it should be concluded that Examinee 2 was characterized by an avoidant style of responding. I am aware that, to some extent, a high value of $L$ is inconsistent with taking into account more than one determinant several times; I nevertheless believe that what might be the case here is two-way reacting: a person either "submits" to the complexity of the stimulus or (more often) reacts in an extremely reserved manner (using exclusively the shape of the inkblot).

Both examinees generated relatively few responses to the multicolored cards in relation to the number of responses they gave to the dark cards. In the Rorschach test this relation is captured in Afr (affective ratio) and interpreted as emotional dependency or lack of emotional dependency on the social environment (Afr was 0.42 for Examinee 1 and 0.47 for Examinee 2). I think these results are within the normal range and the two examinees' emotional reactivity cannot be regarded as excessive [4].

The next step is the comparison of mental resources based on so-called es (experienced stimulation). This comparison provides an insight into the effectiveness of coping with stress and an assessment of whether stress is related to external situations (which are easier to control) or whether it stems from internal determinants associated with deeper predispositions (which are more difficult to overcome). The es index is made up of responses determined by animal movement, the movement of inanimate objects, achromatic color, and all kinds of shading. High es is associated with impulsive and anxious mental regulation and with a sense of permanent overload, unless high es is "balanced" by accessible and well-organized mental potentials (EA). The difference between these two variables speaks about tolerance of stress and at the same time, in some sense, about emotional control (this difference is indicated as D). When the difference does not exceed -2.5 and +2.5 , the results can be regarded as medium. Because Examinee 1 scored 7.5 on EA and 11 on es, in his case the value of $D$ will be -3.5. Examinee 2 scored 5.5 on EA and 5 points on es, which means in his case the value of $D$ will be +0.5 . In Table 10.4 in Exner's manual [4] these results are calculated against the standard deviation, which is equal to 2.5. Thus, in the case of Examinee 1 the result exceeds the standard deviation in the negative direction $(-1)$, while in the case of Examinee 2 it is in the normal range (0). It might, therefore, be suspected that Examinee 1 is less in control of his emotions and more easily succumbs to stress.

But this is not entirely true, as it turns out that the stress experienced by Examinee 1 tends to be transitory and situational, while the resistance to stress shown by Examinee 2 may be overestimated. This is because when all $\mathrm{m}$ scores except one and all Y scores except one are eliminated from es, the obtained value will be Adj es (adjusted es), which will be assessed differently, as the use of inanimate movement (m) and so-called diffuse shading (Y ) are associated with situationally conditioned stress. Thus, the value of Adj es eliminates most of the scores that are associated with situational stress (m, Y). Adj es for the first examinee was 8 , resulting in Adj $D=0.5$, which is interpreted in Table 10.4 [4] as the value of 0 . In the second examinee Adj es was 4, resulting in Adj D $=2.5$, which also gives the value of 0 . It can, therefore, be concluded (based on these particular indices) that the two men do not differ significantly from one another in terms of resistance to stress. But then again, this difference is not entirely unambiguous, as according to Exner Adj es should range between 5 and 9, whereas its value in Examinee 2 is 2.5, which means Adj es is not fully reliable. Therefore, following Exner, it is reasonable to predict that Examinee 2 may have greater difficulties controlling stress than Examinee 1. Examinee 1 scored 8 on Adj es, which can be treated as close to the optimal score, and his negative emotions should be associated with situational stress rather than with stress originating deep inside the psyche regardless of external circumstances.

To sum up the findings presented so far, it can be said that Examinee 2 had lower psychological resources and clearly adopted an avoidant attitude during the test, which can be understood as a defense mechanism against the emotions that the inkblots evoked in him. After a detailed and, I must admit, laborious assessment of coping with stress, it can be concluded that Examinee 1 may have experienced stress more strongly but coped with it well enough. More importantly, his stress was situational, while the results of Examinee 2 were not fully clear, but 
it is legitimate on their basis to suspect that the stress he experienced stemmed from internal problems rather than from the partly understandable stress associated with the very situation of the test.

Social adjustment is measured by the Coping Deficit Index (CDI), developed by Exner [4, 5]. In this index, Examinee 1 scored 2 points and Examinee 2 scored 4 points. To avoid excessive detail in the analysis of results, I do not present the way in which CDI is computed; the interested reader is referred to the manual $[4,5]$. Exner writes that if the value of Adj D is 0 and the value of CDI is lower than 4 , the examinee's stress tolerance and selfcontrol abilities are close to most people's levels of these abilities, and such are the results of Examinee 1. If the value of Adj D is 0 and the value of CDI is at least 4, then it should be concluded that the examinee's personality organization is less mature than should be expected. This kind of person is more easily hurt and does not cope with the stresses of everyday life, particularly when they concern interpersonal relations, and his or her self-control ability is below average [4]. It can, therefore, be concluded that Examinee 1 is able to control his emotions and tolerate stress to a degree sufficient to cope in life, and if he experiences stress, this is usually due to situational factors (es = 11). Examinee 2 may have some adaptation problems, he probably does not cope with negative emotions, and the stress he experiences tends to originate within the psyche, which means it has deeper sources than situational stress.

Moreover, Examinee 2 scored high on the Isolation Index (II). Developed by Exner, this index is computed based on the frequency of contents associated with the natural environment. This includes the following categories: botany (Bt), landscape (Ls), geography (Ge), nature $(\mathrm{Na})$, and clouds $(\mathrm{Cl})$. All contents relevant to this index are added up, and their sum is divided by the total number of responses in the whole test. The values obtained for nature and clouds should be doubled due to the fact that these categories account for the largest proportion of variance. As I have mentioned before, if a response includes $\mathrm{Na}$, none of the remaining categories is scored for this particular response except $\mathrm{Cl}[4,5,8,9$, 10]. The Isolation Index for Examinee 1 was 0.07 , which is very low, whereas the corresponding value for Examinee 2 was 0.39 , which is very high. The lack of a sufficient sense of rootedness in the social environment may increase emotional difficulties in the case of Examinee 2.

The next conclusion is that while Examinee 1 showed good social adjustment and sense of rootedness in the social environment, it can be suspected that Examinee 2 is experiencing adaptation difficulties and a strong sense of loneliness. What also works to the benefit of Examinee 1 is the type of temperament; Examinee 2 may have additional difficulties in this respect, associated with a greater instability of attitudes. All in all, it should nevertheless be admitted that, despite certain emotional problems in Examinee 2, both examinees are individuals with a well socialized emotional sphere.

The Rorschach test is a source of interesting data concerning temperament, which is referred to as experience type. Examinee 1's strongly extratensive (pervasive) type of experience certainly facilitates effective functioning and making decisions. In order to determine experience type, the number of $\mathrm{M}$ responses is compared to $\Sigma \mathrm{C}$; the higher value (in the case of this examinee, 5.5) is divided by the lower value (in this case, 2 ). When the result is higher than 2.5 , it is legitimate to speak of a dominant experience style, in the sense that the experience style manifests itself distinctly. In Examinee 1, due to the predominant use of color, this style is precisely extratensive (Eb Per $=2.75$ ) [5]. In the case of Examinee 2 , the $\mathrm{M}: \sum \mathrm{C}$ ratio was $3: 2.5$. According to Exner, EB Per cannot be computed in this case because the value of $\mathrm{L}$ is too high [4]. It should, therefore, be assumed that Examinee 2 represents an ambitendent style. This kind of style is characterized by a volatility of behavior and a lack of consistency. If they are distinctly present, the two polar experience styles - extratensive and introvertive - have similar power, as they facilitate making decisions and consistently striving in a specific direction. The ambitendent style, by contrast, is not so effective in overcoming situational difficulties [5].

It should be noted that neither of the examinees generated responses determined by color alone (C), and such responses would attest to highly emotional and impulsive behavior. The predominance of form over color in responses is interpreted as indicating the socialization of the emotional sphere. The emotions of Examinee 2 were very efficiently controlled by the intellect $(\mathrm{FC}:(\mathrm{CF}+\mathrm{C})=$ $2.5: 0$ ), while in Examinee 1 the corresponding ratio is 2.5 : 3. Grzywak-Kaczyńska considers the latter pattern of relations between form and color responses to be favorable, assuming that, when they are not too strong and but clear enough, emotions facilitate adjustment [11].

The last aspect of responses that should be considered when deciding on how to interpret $\mathrm{S}$ responses is a more detailed analysis of those feature of responses that may be linked with the quality of interpersonal relations and with self-image. Above all, it should be noted that both examinees spoke about human figures sufficiently often and the percentage of human responses was not too high at the same time $(20 \%$ and $22 \%$, respectively). This may testify to an interest in humans not tinged with anxiety. As I have already mentioned, Exner assesses human responses in terms of content and in terms of formal features, coding them as GHR or 
PHR. As stated before, when analyzing these particular responses given by the two examinees, I followed the rules developed by Exner and I was guided by the numerous examples he cites in his manual [4]. What proved to be difficult to assess was response no. 30 given by Examinee 2; cooperative movement argues for GHR, but classifying this response under the formless $M$ determinant requires classifying it into the PHR category. Examinee 1 gave three responses classified as GHR and three that were classified as PHR. In the case of Examinee 2, there were four GHR responses and four PHR responses. In my view, the differences between the examinees in this respect are not significant. What is more important, however, is that both examinees gave a correct and typically phrased $\mathrm{M}$ response to Card III, which testifies to the absence of really serious problems in relations with other people, especially with significant others. Examinee 1 gave one $\mathrm{M}$ response that did not fit the shape of the inkblot. This kind of reaction always "counts" in the analysis of Rorschach test responses, as all kinds of abnormalities in this respect are often found in people with various disorders, though of course one response of this kind may not be of decisive significance and is not unusual in most examinees. Examinee 2 gave two responses of this kind which is not a positive fact in itself. All three $\mathrm{M}-$ responses given by the two examinees concerned Card X, which is an "emotional" (colorful) one. Though does not fit the shape of the inkblot, the response given by Examinee 1 is fairly often given by Rorschach examinees. Metaphorically, he can, therefore, be said to have taken a false but not particularly unusual path. The second examinee's responses (no. 30 and no. 31), by contrast, were not only incorrect but also unconventional. In response 31, the people seen on the sides of the inkblot as sitting in pews are figures perceived completely inaccurately; the perception of walking people in the center of the inkblot is not correct either. The blue blots in the center of the card, perceived as human figures, are assessed in Exner's manual as interpreted correctly but with the card turned upside down rather than in the original position, as in the case of Examinee 2. One could consider unusual form quality as the category for these figures, but I decided in favor of an overall negative evaluation of form for the whole response.

It can be said that Examinee 2 had more difficulties seeing human figures accurately, particularly those in motion. Rorschach test theorists interpret perceiving human figures in motion as a kind of potential that a person can use in building social relations. This potential is associated with the prototypal role, an important aspect of personality; this role is a way of "projecting" oneself into the future - projecting one's life according to one's own standards and childhood emotional experiences $[3,12]$. It can, therefore, be seen that, despite the correct response to Card III, this examinee is not free from certain difficulties in relations with other people. What is more, let us note that, in half of the cases, the human figures seen in the inkblots had poor form quality, which means it can be said that some negative emotions interfered with the examinee's effective functioning.

Neither of the two examinees used the kind of shading that is associated with impressions of texture (T). This situation makes it reasonable to check what score they have on the Hypervigilance Index (HVI). The score of the first examinee ( 3 points) was in the normal range, while that of the second examinee (4 points) revealed a tendency to remain in a state of hypervigilance, stemming from anxiety and negative anticipation of events. Individuals with this kind of attitude to the world avoid close contacts with others due to the lack of confidence and out of fear of other people's excessive interference in their personal space [5]. Readers interested in computing the value of HVI are referred to the handbooks [4, 5].

To conclude, it should be noted that while Examinee 1 has no difficulties in relations with other people, Examinee 2 perceives others inadequately and negative emotions make it difficult for him to maintain positive relations with them. In addition, he is mistrustful and easily hurt: he expects an unfavorable turn of events and anticipates being harmed by other people.

The two examinees differed significantly in terms of self-esteem. I used the Egocentricity Index (EGOI), developed by Exner. This index, whose accuracy had often disappointed me, proved to be helpful and consistent with the overall picture of the two examinees' psyche this time. EGOI concerns pair responses - i.e., those in which the examinee reports seeing two identical objects - and reflection responses. In order to determine the value of this index, one must add the tripled number of reflection responses to the number of pair responses and then divide the obtained sum by the total number of responses in the entire test. The Egocentricity Index is believed not only to reflect the degree of self-focus but also to relate to selfesteem. If the value of this index is higher than average, it indicates excessive preoccupation with oneself. What plays the key role is the number of reflection responses, as they are interpreted as suggesting narcissistic tendencies. If, despite the high value of the index, there are no reflection responses, it can be suspected that the examinee's self-esteem is not high, and self-focus may stem from a sense of difficulty in relation to oneself. If the EGOI value is below average, particularly when there are no reflection responses, self-depreciation is possible $[4,5]$. According to Exner, the mean value of this index is between 0.33 and 0.45 ; young people (aged 16 and below) have higher EGOI results. Examinee 1 had an EGOI of 
0.37 , which is in the normal range, especially as he spoke about reflections twice. Examinee 2 had a very low EGOI index value of 0.03; he gave no reflection responses at all. It should, therefore, be stressed that this examinee does not have a good opinion about himself, and negative selfesteem may motivate him to take an attitude of defiance and opposition or withdrawal as defense mechanisms.

In the case of Examinee 1, there was one FD score, which attests to a healthy tendency to engage in selfreflection [4, 5]. In the case of Examinee 2, FD occurred as many as three times. Although this score is more often found in adolescents, as many as three FD scores may testify to the examinee being excessively preoccupied with introspection and easily succumbing to depressive moods.

Let us look at the contents of selected response, Examinee 1 saw dancing elephants in Card II. Dancing is a typically human movement, and responses of this kind in the Rorschach test are interpreted as typical of idealists disappointed with the dishonesty and hypocrisy of others; this disappointment may lead to depressive moods or to cynicism and opportunism [3]. It can, therefore, be said that Examinee 1 is experiencing some difficulties associated with evaluating people's conduct that he is unable to take a fully mature attitude towards others. Considering all his Rorschach test results (correct perception of other people, socialized emotional sphere, self-confidence and a positive self-image, a strongly extratensive style of experience that facilitates decision making), these difficulties cannot be regarded as serious. Still, let us note that this examinee gave a "wrong" response to the last card of the test, as if unable to control the accumulated negative emotions. Using the white space in this response introduced an element of criticism, the use of colors tinged it with emotion, and dynamism emphasized its significance to the examinee. The term "odd creature" intensified the expressiveness of the response. I believe this response can be regarded as a key one, symbolically expressing the examinee's basic problem: the problem of other people's dishonest behaviors and the frustration associated with their negative evaluation. This problem has already been signaled with reference to the perception of dancing elephants. I interpret the "dancing elephants" response as an expression of disappointment and a critical attitude towards other people.

I believe that another response - the one about a star on a mast - may also be treated as a key. It can be asked if the star is not a symbol of a guide in the journey of life. The somewhat illogical combination of a ship and a star, due to the low likelihood of this combination in real life, confirms the emotional charge of this image. James P. Choca and Edward D. Rossini [13] supplement the Rorschach test with the Follow-Up Phase, in which the examinee is asked to provide additional information about the responses given, to support them, and to offer their own interpretation. I believe all the three responses I have discussed here would be a rewarding topic to bring up in the Follow-Up Phase.

In the case of Examinee 2, the important human responses were the last two responses to Card X. Card $\mathrm{X}$ is one of the most difficult cards to interpret due to its fragmentation, due to the sense of chaos it evokes, and due to the difficulty involved in proposing a synthetic interpretation. Examinee 2 tried to capture the whole; he succeeded in doing this in response 29 but failed in further two interpretations. Speaking about a ball, he used white space and colors, which increased the emotional level of this response. It was not easy to decide what DQ score to attribute to this response. The examinee himself spoke about a general impression (in that case, a Wv score would be appropriate here), but he did indicate the stairs which he saw in the pink blots and which gave the observation a certain structure, and for this reason I decided to code this response as WS+. However, the figures of people dancing were not identified, the impression of movement was general, and therefore, I chose formless $\mathrm{M}$ as a determinant here. The next and last response was about a church interior with people sitting in pews and with people walking down the nave. In my opinion, the response did not fit the inkblot in terms of form, though I must admit that neither of the responses discussed here is easy to score. Despite the negative assessment in terms of form quality, it should be admitted that both responses were imaginatively sketched. What is important is the presentation of people as a homogeneous mass, a crowd without individual figures identified. The examinee was a narrator who remained outside the scene, as an outsider, was not part of the situation presented, and had a bird'seye view of it. These last two responses correspond with nature, landscape, and botany responses - those based on which the Isolation Index is computed - as a kind of counterpoint: in the examinee's experience, both the world of nature and the social world tell him about his own isolation and loneliness. It is possible to treat the last two responses as keys and ask the examinee to interpret them in the Follow-Up Phase. It is interesting that, when commenting on Card $\mathrm{X}$, both examinees gave responses that amount to a summary of what was the most significant problem for each of them - the problem that can serve as a pivot for discussing the whole test. One may have an impression that, in both examinees, contact with the inkblots initiated work on insight into their own psyche and that this work led to generating images reflecting this insight. 


\section{Discussion}

Let us look again at the obtained results. It can be said that responses of the two examinees did not differ dramatically at first glance. They gave an almost equal identical number of responses and generated a similar number of white space interpretations; moreover, these interpretations were similarly distributed across the test cards. There were no clearly pathological responses, usually coded under some of the special scores. The emotional sphere in both men proved to be sufficiently socialized; they also responded appropriately to Card III, seeing it as presenting dynamic human figures. This response rules out serious abnormalities in prototypal role development. The prototypal role facilitates the basic stabilization of an individual's relations with the social environment and the achievement of goals consistent with their self-concept and view of the world.

However, a detailed analysis of responses revealed differences significant enough to look at Examinee 1 as a well-adjusted person and at Examinee 2 as a person in need of intense help. It also revealed that the examinees' $\mathrm{S}$ responses had different psychological meanings.

In the case of Examinee 1, it is possible to speak of both intellectual consonance, manifesting itself in following lines of thinking similar to those most people follow, and a capacity for original, creative judgments. Good coping with stress and a definitely extratensive style of experiencing the world make it easier for him to make decisions and maintain a certain homogeneity of attitudes. The main asset of this examinee is self-confidence stemming from positive self-esteem. The critical attitude towards the environment, which is a typical attitude of this examinee as an "S person," can be assumed to be at least sometimes constructive and creative. It is also reasonable to suspect that if Examinee 1 expresses his irritation and anger externally, he probably does this in a manner that is within the bounds of socially acceptable conventions. His independent thinking and criticism should win him respect and increase his prestige. Of course, some tensions in relations with other people cannot be ruled out, but Examinee 1 copes with stress well. The whole test supports the conclusion that his critical attitude stems from an idealistic view of the world and disappointment with people, who do not always act nobly.

As regards Examinee 2, it can be said that his $\mathrm{S}$ responses do not show that he evaluates others accurately and offers apt criticism, but rather indicate a generalized attitude of opposition and negativism. This examinee does not always objectively and accurately evaluate life's problems and situations, and his thoughts may too often follow less common paths and may not harmonize with the environment. Additionally, his cognitive processes are easily subject to disorganization as a result of strong negative emotions. The world is not comprehensible enough for him, and his own behaviors are not clear enough and not sufficiently compatible with the expectations of that environment. All of this may increase the sense of mistrust and anxious anticipation of the future failures or wrongs he may experience. The self-esteem of Examinee 2 is definitely low, and the ambitendent experience style makes it difficult for him for him to make decisions and maintain stable attitudes towards life's problems and situations. Moreover, this examinee in unable to cope with stress effectively. His defense mechanisms include unwarranted simplification of the world, withdrawal, and avoidance of excessively complicated situations or ones that are difficult due to their non-formalized character. All this results in Examinee 2 experiencing an acute sense of loneliness and alienation. It can be said that both in the cognitive sphere and in the emotional sphere he functions, as it were, on the margins, without a sense of rootedness in the environment, and that he is focused on brooding over his failures, anticipating an unfavorable turn of events in the future. It is reasonable to suspect that this examinee's emotional problems have their source in childhood and in certain deficiencies regarding prototypal role development.

\section{Conclusions}

The goal I set myself was to show, on two specific cases, how a similar number of white space responses in the Rorschach test can be associated with different psychological characteristics of the responses and how it can be understood in the context of results from the entire test. I found that in Examinee $1 \mathrm{~S}$ responses did not interfere with good adjustment but quite the contrary, they may have been favorable to it. The $\mathrm{S}$ responses generated by Examinee 2 stemmed from his maladjustment and may have been a defense mechanism, increasing his self-esteem and relieving negative emotions. The study confirmed Fonda's position, cited in Introduction, that the characteristics manifesting themselves in $\mathrm{S}$ responses play a positive role in mature people, while in individuals with emotional difficulties, they may be a source of additional difficulties and problems.

Finally, I would like to stress the benefits of this kind of analyses, despite the fact that they are so laborious and toilsome. Firstly, a psychologist does not deal with "abstract" dimensions of personality but has an opportunity to listen to what the examinee is saying, at the same time having knowledge about what psychological meanings may be hidden in that person's responses. Secondly, examinees have a chance, which they usually use in an unconscious manner, to point out to the examiner what is important for them. Moreover, the indices and indicators developed by Exner make the Rorschach test a 
largely objectivized tool, making it possible to measure a variety of mental states and to find support for judgments about examinees. What is important, is that examinees' responses may become the material for conversation with them and that this conversation is not perceived by the examinees as disagreeable interference in their affairs, as the psychologist addresses them using their own words and refers to the images they have generated themselves. It can be said, metaphorically, that the examinee gives the examiner "a part of his or her soul" captured into words and images.

\section{Wstęp}

Celem niniejszego artykułu jest pokazanie, jak w interpretacji plam atramentowych odzwierciedla się ludzkie doświadczanie świata. Uczynię to przez pryzmat tzw. wypowiedzi S. Interpretowanie białego tła, a nie widniejących na nim plam, to zachowanie, które można traktować jako reakcję przeciwną do polecenia; w teście Rorschacha bowiem prosimy badaną osobę o to, by zobaczyła coś w prezentowanych jej plamach, sugerujemy więc, że to właśnie plamy mają być przedmiotem zainteresowania. Skoro badany przenosi swoją uwage na białe tło, możemy odebrać taką reakcję jako postawę negacji buntu, a nawet agresji. Postawa ta może wynikać z cech osobowości badanej osoby, a może być reakcją na sytuację badania. Takie rozumienie opisanego tu zjawiska jest bardzo często spotykane w literaturze, istnieje też niemała liczba danych empirycznych potwierdzającymi takie stanowisko. Nie tak rzadko jednak można spotkać inne opinie badaczy. Wskazują oni także na to, że interpretowanie białego tła, nawet niezależnie od związanej z taką reakcją skłonności do zabarwiania swoich reakcji agresją, wiąże się z dążeniem do autonomii i niezależności a także z oryginalnym i twórczym podejściem do wykonywanego zadania. Charles P. Fonda powołuje się nawet na wskazywane przez psychoanalitycznie zorientowanych psychologów dążenie do osiągnięcia pewnego mistrzostwa w kontrolowaniu i zmienianiu środowiska; dążenie to łączy się z dojrzałością i złożonością psychiki i jest źródłem satysfakcji [1]. Interpretowanie białego tła nazywamy wypowiedziami S ( space reaction); osoby, które często dają wypowiedzi $\mathrm{S}$ będę określała jako „osoby S”. Problematykę związaną $\mathrm{z}$ interpretowaniem białego tła omówiłam w innym miejscu [2]. Z omówienia tego wynika, że wypowiedziom S przypisuje się wiele, często nawet sprzecznych znaczeń psychologicznych. Możemy spotkać wśród „osób S” zarówno osoby silne, pewne siebie i asertywne jaki te, które są słabe psychicznie i które kompensacyjnie, desperacko walczą o zachowanie własnej niezależności i autonomii; o tych ostatnich wspomina Zygmunt Piotrowski, badacz, który jak myślę, należy do tych najwnikliwiej opisujących znaczenia wypowiedzi S i najwyraziściej podkreślający ich wieloznaczność. Piotrowski zwraca uwagę na to, że kompensacyjne reagowanie wypowiedziami $\mathrm{S}$ może łączyć się z niemożnością przeprowadzenia jakichkolwiek zmian, przekracza to bowiem najczęściej możliwości psychologiczne takiej osoby [3, s. 95]. Myślę, że takie przypadki możemy próbować zrozumieć jako przyjęcie postawy opozycji do samego siebie. John E. Exner łączy wypowiedzi S przede wszystkim z negatywizmem, agresją i wrogością. Te stany emocjonalne mogą manifestować się jawnie, w zewnętrznym zachowaniu, ale mogą też być tłumione i ograniczać się do wewnętrznych napięć. Badacz ten podkreśla, że w obu tych przypadkach rezultatem są trudności w utrzymaniu satysfakcjonujących relacji $\mathrm{z}$ innymi ludźmi i nieumiejętność radzenia sobie z bieżącymi problemami życiowymi [4, s. 303]. Ważna jest też według niego sekwencja wypowiedzi typu S. Gdy pojawią się one na pierwsze trzy tablice testu, mają przede wszystkim charakter reaktywny i mogą wypływać albo z negatywnej postawy do samej sytuacji badania, albo łączyć się z bardziej stabilną cechą, związaną z jakimiś problemami dotyczącymi relacji z autorytetem. Jeśli wypowiedzi S pojawią się na dalsze tablice testu, należy brać pod uwagę raczej stałe dyspozycje podmiotu (trait-like-feature) [4, s.327]. Exner pisze, że wszyscy badacze podkreślają, że jeśli dana osoba daje dużo wypowiedzi typu S, może to oznaczać pewne napięcia i konflikty w zderzeniu $\mathrm{z}$ rzeczywistością [4, s.326]. Podobnie mówi Piotrowski - wówczas, gdy walka o zachowanie własnej autonomii staje się podstawową potrzebą i podejmowana jest nawet w sytuacjach, gdy nie ma żadnej presji ze strony otoczenia, może stać się pewnego rodzaju nieprzystosowaniem, a nawet świadczyć o stanach umysłu pokrewnych urojeniom. Badany dający większą liczbę wypowiedzi może S mieć poczucie, że inni ludzie nie akceptuję jego reakcji i postaw, a to oddziela go od otoczenia społecznego i może stać się źródłem konfliktów [ 3, s. 94-95].

Psycholog praktyk stoi więc przed niemałym wyzwaniem związanym $\mathrm{z}$ interpretacją reakcji $\mathrm{S} \mathrm{u}$ konkretnej osoby, którą bada. Wielką pomocą jest w tej sytuacji jedna z najważniejszych zasad interpretacyjnych w teście Rorschacha, a mianowicie to, że znaczenie niemal każdej sygnatury nabiera pewnej specyfiki, gdy rozpatruje się ją na tle całości wyników uzyskanych przez daną osobę. I tak np. Piotrowski za Rorschachem zauważa, że istotne dla interpretacji S są wypowiedzi determinowane samym kolorem lub przewagą koloru nad kształtem (formą). Reagowanie na sam kolor łączy 
się z podatnością na uleganie sugestii i impulsywnością. Im większa przewaga koloru nad formą, a także nad wypowiedziami determinowanymi ruchem ludzkim, tym większe prawdopodobieństwo, że $\mathrm{S}$ zamanifestuje się w zewnętrznej opozycji, nieposłuszeństwie, kłótliwości i zachowaniach prowokacyjnych. I odwrotnie, przy dobrej kontroli emocji i dostatecznym uspołecznieniu ( o czym w teście plam mówić ma przewaga determinanty kształtu nad determinantą koloru przy formowaniu wypowiedzi), podwyższona liczba S będzie uprawdopodabniać takie pozytywne cechy, jak twórcza asertywność, energia i oryginalność myśli a krytyczna postawa do otoczenia może mieć konstruktywny charakter. Nawet wówczas jednak należy liczyć się z tym, że badana osoba może odczuwać brak satysfakcji w radzeniu sobie z problemami życiowymi i z samą sobą, co może prowadzić do poczucia frustracji i związanego z nią, wtórnego, wyższego poziomu agresji [ 4, 5 ].

Jak widzimy, badani uzyskujący podwyższoną liczbę S mogą się istotnie różnić między sobą. Mogą znaleźć się tu ci, którzy mają konflikty z prawem ale też ci, którzy reprezentują prawidłową hierarchię wartości; podobnie nierzadko należeć tu będą osoby słabe i niepodatne na zmiany, jak i osoby $\mathrm{z}$ dużym potencjałem energii i dobrą prognozą w psychoterapii. Myślę, że należy docenić intuicję Piotrowskiego, który zwraca uwagę na związek białego tła z depresyjnością. Nierzadko w takich przypadkach badani widzą w białych plamach pustkę lub nicość, co może być interpretowane symbolicznie [3].

Podsumowując, przetoczę pokrewny Piotrowskiemu pogląd Fondy: „It is not unreasonable, of course, to assume that $\mathrm{S}$ may be related to adaptive behaviour in emotionally mature individuals and to maladaptive behaviour in the disturbed" [1, s. 143].

W artykule tym porównam wypowiedzi uzyskane od dwu mężczyzn badanych testem Rorschacha. Porównanie to dotyczy interpretacji, jakie można nadać w obu tych przypadkach wypowiedziom typu S. Abstrahuję od danych dotyczących samych badanych jako osób, podając jedynie informacje o ich płci i wieku (mężczyzna nr 1 miał 30 lat, mężczyzna nr 2 zaś 20 lat). Czynię tak dlatego, iż pragnę zająć się tu jedynie wypowiedziami S w kontekście całego badania, nie jest to studium dwóch przypadków; uzyskane wypowiedzi traktuję jako pewną autonomiczną całość, tekst i aż do ostatecznych wniosków chciałabym inne informacje dotyczące badanych zostawić na boku, ważne jest bowiem dla mnie wykazanie siły znaczeń kryjących się w sposobach interpretacji plam.

\section{Materiał i metoda}

Procedura badania a także sygnowanie i interpretowanie wypowiedzi odpowiadało systemowi opracowanemu przez Exnera ( The Comprehensive
System ). Decyzja wyboru tego systemu podyktowana była tym, że dostarcza on, w mojej ocenie, najbardziej wyczerpującą ocenę wypowiedzi badanych osób. W systemie tym, pierwszy krok $\mathrm{w}$ analizie wypowiedzi badanych, to zasygnowanie wypowiedzi w tej kolejności, w jakiej były podane (Exner nazywa wyniki tej procedury Sequence of Scores). Załączę więc wszystkie wypowiedzi testowanych mężczyzn, zarówno te podane $\mathrm{w}$ fazie właściwego badania, jak i niektóre $\mathrm{z}$ tych wypowiedzi, które zostały podane $\mathrm{w}$ fazie tzw. sprawdzania wypowiedzi, a następnie przedstawię zasygnowanie tych wypowiedzi. W ocenie adekwatności wypowiedzi w stosunku do prezentowanych badanym bodźców, posługiwałam się przykładami podanymi w odpowiednich tablicach w podręczniku Exnera z 2003 roku. Rezygnuję z przedstawienia wyników kolejnego etapu przetworzenia danych (wyższego poziomu analizy), którego wynikiem są dane strukturalne (Exner posługuje się tu terminem Structural Sumary) [4, 5], zawierające różne pogrupowania poszczególnych sygnatur, oceny liczbowe oraz wartości licznych indeksów i wskaźników. Pominięcie załączenia Structural Summary (pozostaje ona $\mathrm{w}$ dokumentacji u autorki) podyktowane zostało względami praktycznymi. Wyjaśnienie wszystkich danych zawartych w Structural Summary, nie zawsze byłoby bezpośrednio związane $\mathrm{z}$ wypowiedziami $\mathrm{S}$, a wymagałoby rozszerzenia objętości tego artykułu ponad miarę. Ze Structural Summary więc wybiorę tylko niektóre, najistotniejsze elementy. Mówiąc ogólnie, będą to przede wszystkim te cechy wypowiedzi, które należy wiązać z efektywnością i oryginalnością procesów poznawczych, sferą emocjonalną i przystosowaniem społecznym.

Do analizy wybrałam dwu badanych, których protokoły mają niemal równą liczbę wypowiedzi podanych w całym badaniu. Mimo że poszczególne typy wypowiedzi ocenia się $\mathrm{w}$ odniesieniu do ich liczby, wielu badaczy podkreśla znaczenie absolutnej liczby wypowiedzi, czyli wszystkich wypowiedzi podanych przez daną osobę w całym badaniu, liczba ta może bowiem wpływać na ujawnienie się niektórych cech reagowania. Gdy weźmiemy pod uwagę charakter wypowiedzi obu badanych, można ogólnie powiedzieć, że na „pierwszy rzut oka" nie było między nimi dramatycznych różnic, dokładniejsza analiza jednak ujawniła niemałe problemy jednego $\mathrm{z}$ nich. Jest to zgodne $\mathrm{z}$ moim zamierzeniem, dążyłam bowiem do tego, by różnice związane ze znaczeniami wypowiedzi S ujawniły się jak najwyraźniej.

Mężczyzna nr 1 (30 wypowiedzi) interpretował białe tło pięć razy a mężczyzna nr 2 siedem razy. Myślę, że choć różnica ta nie jest zupełnie bez znaczenia, obaj badani mogą być zaliczeni pod tym względem do jednej kategorii. Exner uważa, że jeśli nie ujawni się żadna wypowiedź 
typu S lub jeśli będą dwie takie wypowiedzi, można uznać to za sytuację niezbyt znaczącą. Jeśli wystąpią trzy S, ale dotyczyć będą one dwóch pierwszych tablic, możemy mówić o negatywistycznym stosunku do samego badania. Jeśli mamy do czynienia z czterema lub pięcioma $S$, ale podanymi na trzy pierwsze tablice testu, możemy wnosić, że badany jest zirytowany sytuacją badania. Nie musi się to wiązać ze stałą cechą osobowości, ale należy liczyć się z tym, że badany często może reagować negatywizmem i buntem wówczas, gdy jest konfrontowany z niechcianymi wyzwaniami lub gdy ma jakieś problemy w relacji do autorytetu. Exner wskazuje, że istotne znaczenie dla interpretacji wyników testu mają dwa przypadki. Pierwszy z nich dotyczy sytuacji, gdy występują trzy S i jedno z nich podane jest na tablicę dalszą niż II. Świadczy to o tym, że badany jest bardziej opozycyjny niż większość ludzi. Opozycyjność ta nie musi być zbyt obciążająca dla funkcjonowania badanego, ale może zakłócać harmonijność jego relacji społecznych. Drugi przypadek to wystąpienie czterech S lub większej ich liczby przy tym, że przynajmniej jedno S jest podane na tablicę dalszą niż III. Możemy wówczas przypuszczać, że u badanego poziom negatywnych emocji (złości) jest zdecydowanie wyższy niż przeciętny i wpływa na jego funkcjonowanie, na podejmowanie decyzji a także na radzenie sobie w relacjach $\mathrm{z}$ innymi ludźmi. Ten sposób reagowania to raczej względnie trwała cecha osobowości ( trait- like feature) a nie wyraz negatywnego stosunku testowanej osoby do badania jako takiego. Obaj mężczyźni wybrani do analizy odpowiadają temu właśnie przypadkowi. Rozkłady podanych przez nich wypowiedzi S są w miarę równomiernie rozłożone poprzez wszystkie dziesięć tablic testu (mężczyzna nr 1: II, IV, VII, X; mężczyzna nr 2: II, III, VII, X).

A oto wypowiedzi mężczyzny $\mathrm{nr} 1$ (w nawiasach podaję te wyjaśnienia z fazy sprawdzania, które uważam za istotne).

I

1. ćma (ma kształt ćmy i typowy dla niej, szary, nierównomierny kolor)

2. część szkieletu człowieka ( widać zacieniowane kości i ich układ)

3. dwie głowy ptaka, lustrzane odbicie ( widać ich upierzenie i niejednolitość koloru

4. ̇uk ( po prostu wygląda jak żuk)

II

5. dwa tańczące słonie

6. lecący samolot

7. < króliczki (jakby biegły)

8. $\quad v$ eksplozja, jakiś wybuch ( widać jak wybucha i czerwień, o tym świadczą też, takie czerwone rozbryzgi)

9. kotek (no, tutaj on jest, tu oczy, uszka)
III

10. dwoje ludzi ( robią coś )

11. motyl czerwony ( kształt motyla)

IV

12. jakiś krab, coś takiego

13. głowa wielbłąda

14. głowy ptaka ( kształt głowy i dziób)

15. człowiek $\mathrm{z}$ żabiej perspektywy (z dołu fotografowany daje taki kształt, to tyle)

$\mathrm{V}$

16. motyl w locie

17. nietoperz w locie

VI

18. coś w rodzaju gwiazdy na maszcie

19. twarze odbite

VII

20. głowa w hełmie

21. twarz jakiegoś potwora ( zwierzę, widać zarysy oczu poprzez to zacieniowanie, to było ważne)

VIII

22. dwa idące drapieżniki (różowy kolor, to też pomogło je zobaczyć)

23. góra ( taka szara jak na obrazkach, takie różowe)

24. tarczyca ( zabarwiona kolorami, kształt tarczycy ma)

25. strzała jakaś

IX

26. dwa jakieś potwory ryczące symetrycznie, zielone

27. głowa i część korpusu, kosmity może

$\mathrm{X}$

28. twarz jakiegoś dziwoląga, oczy, brwi, zdziwienie, konfuzja ( z powodu kolorów mówię, że to dziwoląg)

29. zamek na szczycie góry

30. plankton ( kolory i kształty planktonu)

Po numerze oznaczającym kolejność wypowiedzi można znaleźć znaczek > lub v, oznacza on boczną lub odwróconą pozycję tablicy. W nawiasie podane są ważniejsze wypowiedzi uzyskane $\mathrm{w}$ fazie sprawdzania. W Tabeli1 w pierwszej kolumnie, nie licząc kolejności tablic i kolejności wypowiedzi, zawarte są oznaczenia dotyczące obszarów plamy, które były interpretowane oraz typ lokalizacji. W to interpretacja całej plamy; D to interpretacja dużej, dobrze wydzielonej plamy; Dd to interpretacja małej lub słabiej wydzielonej części plamy; $S$ to interpretowanie białego tła. Białe tło może być kombinowanie z całą plamą (WS) lub jej częścią (DS, DdS), ale nawet wówczas, gdy brane jest pod uwagę tylko białe tło, w systemie Exnera zaznacza się, czy jest to duży (WS, DS) czy mały (DdS) obszar. W powyższym przykładzie występują dwa typy lokalizacji: lokalizacja zwykła (o), 
Tabela 1. Sekwencja sygnatur

\begin{tabular}{|c|c|c|c|c|c|c|c|}
\hline Tablica & $\begin{array}{c}\text { Numer } \\
\text { wypowiedzi }\end{array}$ & $\begin{array}{l}\text { Obszar i typ } \\
\text { lokalizacji }\end{array}$ & $\begin{array}{l}\text { Determinanta i } \\
\text { poziom formy }\end{array}$ & Treść & $\begin{array}{l}\text { Wypowiedzi } \\
\text { popularne }\end{array}$ & Wartość Z & $\begin{array}{l}\text { Sygnatury } \\
\text { Specjalne }\end{array}$ \\
\hline \multirow[t]{4}{*}{ I } & 1. & Wo & FYo & A & & 1.0 & \\
\hline & 2. & Wo & YF- & An & & 1.0 & \\
\hline & 3. & D+ & YF.Fr.o (2) & $\mathrm{Ad}$ & & 6.0 & \\
\hline & 4. & Do & Fo & A & & & \\
\hline \multirow[t]{5}{*}{ II } & 5. & D+ & $\mathrm{M}^{\mathrm{a}} \mathrm{o}(2)$ & A & $\mathrm{P}$ & 3.0 & \\
\hline & 6. & DSo & $\mathrm{m}^{\mathrm{a}} \mathrm{O}$ & Sc & & & \\
\hline & 7. & Do & $\mathrm{FM}^{\mathrm{a}} \mathrm{O}$ & A & & & \\
\hline & 8. & Do & $\mathrm{m}^{\mathrm{a}} \cdot \mathrm{FCo}$ & Ex & & & \\
\hline & 9. & DdSo & $\mathrm{Fu}$ & A & & 4.5 & \\
\hline \multirow[t]{2}{*}{ III } & 10. & $\mathrm{D}+$ & $\mathrm{M}^{\mathrm{a}} \mathrm{o}(2)$ & $\mathrm{H}$ & $\mathrm{P}$ & 3.0 & GHR \\
\hline & 11. & Do & FCo & $\mathrm{Ad}$ & & & \\
\hline \multirow[t]{4}{*}{ IV } & 12. & Wo & F- & A & & 1.0 & \\
\hline & 13. & Do & $\mathrm{Fu}$ & $\mathrm{Ad}$ & & & \\
\hline & 14. & DSo & Fo & $\mathrm{Ad}$ & & 5.0 & \\
\hline & 15. & Wo & FDo & $\mathrm{H}$ & $\mathrm{P}$ & 2.0 & \\
\hline \multirow[t]{2}{*}{ V } & 16. & Wo & $\mathrm{FM}^{\mathrm{a}} \mathrm{O}$ & A & $\mathrm{P}$ & 1.0 & \\
\hline & 17. & Wo & $\mathrm{FM}^{\mathrm{a}} \mathrm{O}$ & A & $\mathrm{P}$ & 1.0 & PSV \\
\hline \multirow[t]{2}{*}{ VI } & 18. & W+ & F- & Sc & & 2.5 & INCOM1 \\
\hline & 19. & $\mathrm{D}+$ & Fru & $\mathrm{Hd}$ & & 2.5 & PHR \\
\hline \multirow[t]{2}{*}{ VII } & 20. & DS+ & $\mathrm{Fu}$ & $\mathrm{Hd}, \mathrm{Cg}$ & & & PHR \\
\hline & 21. & Do & YFo & $\mathrm{Ad}$ & & & DV1 \\
\hline \multirow[t]{4}{*}{ VIII } & 22. & Do & $\mathrm{FM}^{\mathrm{a}} \cdot \mathrm{FCo}(2)$ & A & $\mathrm{P}$ & & \\
\hline & 23. & Do & CFo & Ls & & & \\
\hline & 24 & Do & CF- & An & & & \\
\hline & 25 & Ddo & F- & Sc & & & \\
\hline \multirow[t]{2}{*}{ IX } & 26 & D+ & $\mathrm{FM}^{\mathrm{a}}$.FCo (2) & A & & & DV1 \\
\hline & 27 & Do & $\mathrm{Fu}$ & (Hd) & & & GHR \\
\hline \multirow[t]{3}{*}{$\mathrm{X}$} & 28 & DSo & $\mathrm{M}^{\mathrm{a}}$.FC- & $\mathrm{Hd}$ & & 6.0 & PHR \\
\hline & 29 & DS+ & $\mathrm{FCu}$ & Sc, Ls & & 6.0 & \\
\hline & 30 & Do & $\mathrm{FCu}$ & A & & & \\
\hline
\end{tabular}

którą stwierdzamy, gdy widziany jest jeden obiekt o określonym kształcie oraz lokalizacja syntetyczna (+), którą stwierdzany wówczas, gdy wypowiedź dotyczy dwóch obiektów, które spostrzegane są jako odrębne, ale pozostające we wzajemnej relacji i gdy przynajmniej jeden $\mathrm{z}$ tych obiektów jest determinowany kształtem plamy. Typ lokalizacji to inaczej tzw. Developmental Quality (DQ), czyli jakość rozwojowa. DQ to ocena stopnia wykorzystania struktury plamy w procesie formowania wypowiedzi. W przedstawionym protokole mamy dwa typy lokalizacji: +, gdy osoba badana spostrzegała odrębne obiekty połączone jakąś sensowną relacją lub o, czyli jakość „oczywista”, gdy badany spostrzegał jeden obiekt o określonym kształcie.

W drugiej kolumnie zawarte są determinanty wypowiedzi i poziom adekwatności danego spostrzeżenia do bodźca, jeśli uwzględniona jest determinanta F. F oznacza kierowanie się kształtem plamy, C kierowanie się kolorem, FC kierowanie się przede wszystkim kształtem, ale przy uwzględnieniu koloru, CF kierowanie się 
kolorem, ale przy jednoczesnym uwzględnieniu kształtu. $\mathrm{Y}$ to kierowanie się tzw. rozlanym światłocieniem i możliwe są tu kombinacje analogiczne do kombinacji determinanty kształtu i determinanty koloru. FD to spostrzeżenie perspektywy (przestrzenności) uwarunkowanej kształtem i wielkością plam. (2) to oznaczenie wypowiedzi, która mówi o parach obiektów, Fr zaś to oznaczenie wypowiedzi mówiącej o odbiciach. M to wypowiedź mówiąca o ruchu ludzkim, FM o ruchu zwierzęcym, m o ruchu przedmiotów nieożywionych. Mała literka a oznacza ruch aktywny (w przeciwieństwie do ruchu biernego, pasywnego, oznaczonego małą literką $^{\mathrm{p}}$ ). $\mathrm{W}$ prezentowanym badaniu wystąpiły trzy oceny poziomu formy: o to wypowiedź oczywista; u to wypowiedź unikatowa, czyli wymagająca nieco wysiłku, by zobaczyć to, co widzi w plamie osoba badana; - to wypowiedź nieadekwatna do plamy.

W trzeciej kolumnie oznaczona jest treść wypowiedzi. H to człowiek, Hd to część człowieka, (Hd) to część człowieka określanego jako postać baśniowa, fantastyczna. A to zwierzę a Ad to część zwierzęcia. Sc to przedmioty związane $\mathrm{z}$ osiągnięciami nauki lub rzemiosła, An to anatomia, Ex to wybuch, Cg to ubiór a Ls to krajobraz. P oznacza, że wypowiedź należy do wypowiedzi popularnych, a następnie zapisuje się liczbę punktów tzw. Z, które nadaje się za stopień organizacji pola bodźcowego. Mamy cztery typy wypowiedzi, którym można przypisać wartość Z: wypowiedź interpretująca całą plamę (przy typie lokalizacji syntetycznej lub oczywistej); wypowiedź uwzględniająca detale graniczące ze sobą jako pozostające w pewnej relacji; wypowiedź uwzględniająca detale powiązane wzajemnie ale nie graniczące ze sobą; wypowiedź łącząca białe tło z jakimś obszarem plamy (te ostatnie wypowiedzi są na ogół oceniane najwyżej). Punkty Z mogą być nadane jedynie tym wypowiedziom, które uwzględniają kształt plamy. Ostatnia kolumna to tzw. sygnatury specjalne, które oznaczają różne rodzaje nieprawidłowości zawarte w wypowiedzi albo dodatkowe cechy wypowiedzi. W naszym przykładzie jest to przede wszystkim GHR i PHR. Oznaczenia te dotyczą wypowiedzi mówiących o postaci ludzkiej (Good Human Representational Response, Poor Human Representational Response). Ze względu na pewną zawiłość kryteriów oceny, które wypowiedzi zaliczyć należy do GHR, a które do PHR, nie będę ich tu przytaczać, a raczej odeślę czytelnika do wytycznych podanych przez Exnera [4]. Ogólnie można powiedzieć, że preferowane jest spostrzeganie całej postaci ludzkiej w kontekście pozytywnego zabarwienia emocjonalnego. Premiowany jest też dobry poziom formy, czyli adekwatność wypowiedzi do bodźca i brak w niej poważniejszych nieprawidłowości (chodzi tu zwłaszcza o niektóre sygnatury specjalne). U badanego nr 1 wystąpiły trzy sygnatury GHR i trzy sygnatury PHR. DV to przede wszystkim zaskakujące lub niewłaściwe słowa użyte w wypowiedzi. U mężczyzny nr 1 były to bardzo subtelne i często spotykane nieprawidłowości (np. wyraz "twarz" w odniesieniu do zwierzęcia i nieco dziwaczne określenie ryczenia potworów jako ryczenia wykonywanego symetrycznie). Obie sygnatury DV należą do pierwszego, mniej patologicznego poziomu, co oznaczone jest cyfrą 1. Wystąpiło też jedno nielogiczne zestawienie (INCOM), również ocenione jako należące do poziomu 1. Inna sygnatura specjalna to PSV, czyli perseweracja. Występuje ona wówczas, gdy badany powtarza tę samą treść (spotykamy się z tym w analizie przypadku nr 2) lub też, gdy występują wypowiedzi bardzo zbliżone do siebie w treści i o tych samych sygnaturach w obrębie tej samej tablicy (w przypadku nr 1 chodzi tu o wypowiedzi podane na tablicę V).

Ważne jest zwrócenie uwagi na piątą $\mathrm{z}$ kolei wypowiedź podaną na tablicę II. Treść tej wypowiedzi dotyczy słoni, a więc jej treścią są zwierzęta. Zwierzęta te jednak wykonują czynność typową dla ludzi ( nie ma żadnego wyjaśnienia, że są to np. słonie w cyrku), a więc wypowiedź ta determinowana jest ruchem ludzkim.

A oto wypowiedzi mężczyzny $\mathrm{nr} 2$.

I

1. nietoperz ( tu skrzydła, tu tułów)

2. jakiś motyl ( podobnie jak nietoperz ma skrzydła itd.)

3. jakiś owad ( też tak samo)

II

4. jakaś twarz, jakiegoś zwierzęcia, człowieka ( pytanie osoby badającej: zwierzęcia czy człowieka? To i to (?) raczej człowieka)

5. jakiś statek kosmiczny, pojazd

6. jakaś wyspa, skały, laguna ( laguna tu, a skały dalej, w tyle, (?) są mniejsze )

7. ludzie, coś robią, w rzece coś piorą ( w szarej plamie na dole kształt takich „dziobków” widzę, jako fale na lśniącej powierzchni)

8. twarz, tak jakby zwierzęcia

9. wazon

IV

10. to drzewo ( po prostu kształt drzewa i cienie robią, że tak jakby różne listowie było)

11. jakiś duży koleś, facet, duży olbrzym

12. statek kosmiczny

$\mathrm{V}$

13. to już na pewno nietoperz

14. jakiś ptak może

15. do pojazdu kosmicznego, wszystko to jest podobne 
Tabela 2. Sekwencja sygnatur

\begin{tabular}{|c|c|c|c|c|c|c|c|}
\hline Tablica & $\begin{array}{c}\text { Numer } \\
\text { wypowiedzi }\end{array}$ & $\begin{array}{c}\text { Obszar i typ } \\
\text { lokalizacji }\end{array}$ & $\begin{array}{l}\text { Determinanta i } \\
\text { poziom formy }\end{array}$ & Treść & $\begin{array}{l}\text { Wypowiedzi } \\
\text { popularne }\end{array}$ & Wartość Z & $\begin{array}{l}\text { Sygnatury } \\
\text { specjalne }\end{array}$ \\
\hline \multirow[t]{3}{*}{ I } & 1. & Wo & Fo & A & $\mathrm{P}$ & 1.0 & \\
\hline & 2. & Wo & Fo & A & $\mathrm{P}$ & 1.0 & PSV \\
\hline & 3. & Wo & F- & A & & 1.0 & \\
\hline \multirow[t]{3}{*}{ II } & 4. & WSo & F- & $\mathrm{Hd}$ & & 4.5 & PHR \\
\hline & 5. & Wo & F- & $\mathrm{Sc}$ & & 4.5 & \\
\hline & 6. & $\mathrm{Wv}$ & FDu & $-\mathrm{Na}$ & & 4.5 & \\
\hline \multirow[t]{3}{*}{ III } & 7. & $\mathrm{D}+$ & $M^{\mathrm{a}} \cdot \mathrm{m}^{\mathrm{p}} . \mathrm{Yo}$ & $\mathrm{H},-\mathrm{Na}$ & $\mathrm{P}$ & 3.0 & GHR \\
\hline & 8. & DSo & F- & $\mathrm{Ad}$ & & 4.5 & DV1 \\
\hline & 9. & Ddo & F- & Art & & & \\
\hline \multirow[t]{3}{*}{ IV } & 10. & Wo & FYo & $\mathrm{Bt}$ & $\mathrm{P}$ & 2.0 & \\
\hline & 11. & Ddo & Fo & $\mathrm{H}$ & & & GHR \\
\hline & 12. & Wo & $\mathrm{Fu}$ & Sc & & 2.0 & PSV \\
\hline \multirow[t]{3}{*}{$\mathrm{V}$} & 13. & Wo & Fo & A & $\mathrm{P}$ & 1.0 & \\
\hline & 14. & Wo & Fo & A & & 1.0 & PSV \\
\hline & 15. & Wo & $\mathrm{Fu}$ & $\mathrm{Sc}$ & & 2.5 & PSV \\
\hline \multirow[t]{3}{*}{ VI } & 16. & Wo & $\mathrm{Fu}$ & Sc & & 2.5 & \\
\hline & 17. & Wo & $\mathrm{FM}^{\mathrm{p}} \mathrm{O}$ & A & & 2.5 & \\
\hline & 18. & Wo & $\mathrm{Fu}$ & Ay & & 2.5 & \\
\hline \multirow[t]{3}{*}{ VII } & 19. & DSv & $\mathrm{Fu}$ & $\mathrm{Na}$ & & & \\
\hline & 20. & Do & F- & Hd & & & PHR \\
\hline & 21. & WSo & F- & (Hd) & & 4.5 & GHR \\
\hline \multirow[t]{4}{*}{ VIII } & 22. & W+ & $F^{a}{ }^{a} 0 .(2)$ & A & $\mathrm{P}$ & 3.0 & \\
\hline & 23. & $\mathrm{Dd}+$ & F- & Sc, Ls & & & \\
\hline & 24 & Wo & $\mathrm{Fu}$ & Art & & 4.5 & \\
\hline & 25 & Wo & $\mathrm{Fu}$ & $\mathrm{Sc}$ & & 4.5 & PSV \\
\hline \multirow[t]{3}{*}{ IX } & 26 & Ddo & $\mathrm{FCu}$ & $(\mathrm{Hd})$ & & & GHR \\
\hline & 27 & $\mathrm{~W}+$ & FC.FDu & $\mathrm{Hh}, \mathrm{Bt}$ & & 5.5 & \\
\hline & 28 & Do & FCo & $\mathrm{Bt}$ & & & \\
\hline \multirow[t]{3}{*}{$\mathrm{X}$} & 29 & DdS+ & FC.FDu & $\mathrm{Sc},-\mathrm{Na}$ & & 6.0 & \\
\hline & 30 & WS+ & Formless $\mathrm{M}^{\mathrm{a}}$.FC- & $\mathrm{H}, \mathrm{Sc}$ & & 5.5 & COP, PHR \\
\hline & 31 & $\mathrm{~W}+$ & Ma- & $\mathrm{H}, \mathrm{Sc}$ & & & PHR \\
\hline
\end{tabular}

VI
16. pojazd kosmiczny, nawet bardziej tu
17. zwierzę jakieś ( jakby tak leżało, tu nogi, rozklapnięte, tu wąsy)
18. maczuga

VII

19. to wygląda jak jakieś jezioro

20. tak jakby ręce były, (cztery, dłonie, z kciukiem)

21. jakaś maska ( do zakrywania twarzy)
VIII

22. jakieś dwa zwierzaki, wspinają się

23. jakaś chatka ( żółtawa część pomarańczowej plamy to skały, różowa część to podstawa chatki)

24. też jakiś puchar

25. jakiś pojazd kosmiczny

IX

26. twarz jakiegoś stwora ( z filmu „Hellboy”) (był 
to król lasu, wyrósł z ziarenka, dlatego kolory też muszą tu być)

27. jakiś koszyk z owocami ( owoce są bliżej, koszyk w tylnym planie, owoce, to trzeba też i kolory uwzględnić)

28. kwiaty ( mają swój kształt, ale kwiaty są też kolorowe!)

$\mathrm{X}$

29. jakiś staw i przy stawie wejście do jakiegoś budynku, tunelu, tunel jest daleko, jest mały tam, że kolor różowy i szary to pasuje

30. sala zamkowa, jakaś zabawa, ogólne wrażenie, ludzie tańczą, różowe to schody, kolory pomagają

31. kościół, po bokach ludzie w ławkach, ołtarz, w środku ludzie idą

Jak widać w Tabeli 2, w przypadku mężczyzny nr 2 pojawiło się kilka nowych oznaczeń, np. M bez formy to sygnatura, którą stosujemy wówczas, gdy wypowiedź determinowana jest ruchem ludzkim, ale to odczucie ruchu polega na ogólnym wrażeniu, nie związanym z żadnym konkretnym kształtem. W kolumnie treści pojawiła się sygnatura $\mathrm{Na}$, która oznacza zjawiska natury, Bt którą przypisujemy roślinom, Art którą przyznajemy treściom związanym ze sztuką, Hh utworzoną dla oznaczenia przedmiotów związanych z gospodarstwem domowym i w końcu Ay, która łączy się $\mathrm{z}$ treściami antropologicznymi. Jeśli $\mathrm{w}$ treści pojawia się symbol $\mathrm{Na}$, należy pominąć inne treści związane z obliczaniem indeksu izolacji, takie jak Bt i Ls. W kolumnie sygnatur specjalnych pojawiło się oznaczenie COP. Jest ono przypisywane tym wypowiedziom, które mówią o współpracy lub o pozytywnej relacji między dwoma lub między większą liczbą obiektów (oceniam, że wspomniana w wypowiedzi nr 30 zabawa w sali balowej zakłada jakieś współdziałanie ludzi ze sobą i pozytywne relacje między nimi). Wypowiedź nr 6 i nr 19 zostały ocenione jako lokalizacja Wv, czyli lokalizacja wieloznaczna, którą sygnujemy wówczas, gdy badany interpretuje plamę jako coś o nieokreślonym kształcie, tam gdzie kształt nie jest istotny dla spostrzeganego obiektu i jest czymś, co może się zmieniać. Reakcje tego typu nie wymagają strukturyzacji bodźca, pozostają najczęściej ogólnym wrażeniem.

Jak już wspomniałam, w porównywaniu wyników uzyskanych od obu badanych wykorzystuję te elementy Structural Summary, które uznaję za istotne w interpretacji wypowiedzi S.

\section{Wyniki}

W ocenie funkcjonowania poznawczego najbardziej podstawowa jest adekwatność wypowiedzi do prezentowanych badanym plam. Procent wypowiedzi nieadekwatnych (minusowych) wynosił 20 (dla badanego $n r$ 1) i 29 ( dla badanego $n r$ 2). Jest to liczba wyższa niż ta, jaka zwykle występuje u osób zdrowych. Mimo to myślę, że w tych dwu przypadkach wysoki procent wypowiedzi nieadekwatnych do bodźców odzwierciedla raczej swobodne podejście do badania i brak chęci „wykazania się za wszelką cenę "niż niedostatek inteligencji. Taką interpretację uzasadnia w pewnym stopniu to, że u obu badanych nie wystąpiły wypowiedzi o bardzo dobrym poziomie formy, odznaczające się wysoką precyzją i szczegółowością opisu spostrzeganego kształtu. Tego typu wypowiedzi świadczą nie tylko o dobrym intelekcie, ale również nierzadko o wysokiej motywacji, by w badaniu wypaść jak najlepiej. Podobnie, o chęci zaimponowania świadczyć może zwiększona liczba wszystkich wypowiedzi, ta jednak u obu mężczyzn nie przekraczała przeciętnych wartości. Przyjmuję, że krytyczną wartością dla procentu wypowiedzi „minusowych” jest 29, ponieważ w indeksie zaburzeń percepcji i myślenia (PTI) liczba ta stanowi pułap graniczny; wartość większa niż 29 świadczy już o jakiś nieprawidłowościach. Mimo to należy przyznać, że procesy poznawcze badanego $\mathrm{nr} 2$, były znacząco "gorsze" niż procesy poznawcze badanego nr $1 \mathrm{i}$ fakt ten wymaga wyjaśnienia.

Obaj mężczyźni różnili się też wyraźnie w liczbie wypowiedzi o oczywistym poziomie formy (o) (17 u pierwszego i $10 \mathrm{u}$ drugiego). Niska liczba tych wypowiedzi u mężczyzny $\mathrm{nr} 2$ wiązała się z wysoką liczbą wypowiedzi o unikatowym poziomie formy $(42 \% \mathrm{w}$ stosunku do wszystkich reakcji danych w całym badaniu). Wypowiedzi unikatowe (u) to wypowiedzi adekwatne do prezentowanych bodźców, ale nie narzucające się $\mathrm{w}$ sposób oczywisty, a przede wszystkim dużo rzadziej spotykane wśród badanych. Nie można powiedzieć, by wypowiedzi te wprost świadczyły o gorszym funkcjonowaniu poznawczym, ale zdecydowanie mówią one o tym, że ich autor albo nie liczy się z konwencjami albo o tym, że jego myśl podąża mniej popularnymi szlakami - w obu tych wypadkach jednak można spodziewać się, że zachowania badanego nie zawsze muszą być w pełni zrozumiałe i akceptowalne społecznie. Exner podaje, że procent wypowiedzi unikatowych zwykle nie przekracza 25, a wyższy niż 30 stanowi już poważny problem [4]. U mężczyzny $\mathrm{nr} 2$ procent wypowiedzi unikatowych był więc zdecydowanie bardzo wysoki. Procent wypowiedzi odpowiadających oczywistemu poziomowi formy jest jednocześnie procentem wypowiedzi $\mathrm{X}+, \mathrm{X}+$ bowiem to suma wypowiedzi oczywistych i bardzo dobrych ( a tych ostatnich u obu badanych nie zaobserwowałam).

Następnym ważnym wskaźnikiem efektywności procesów poznawczych jest procent wypowiedzi S- (liczony w stosunku do wszystkich wypowiedzi minusowych). U mężczyzny $\mathrm{nr} 1$ procent ten wyniósł 
17, u mężczyzny nr 2 aż 36. Exner za wartość graniczną S- \% przyjmuje 33 [6]. Gdy osoba badana uzyska wyższy niż 33\% tego typu wypowiedzi, należy liczyć się z tak silnym negatywizmem lub złością, że zaburzają one funkcjonowanie poznawcze. Badania empiryczne wskazują, że podwyższone wyniki S- \% szczególnie często występują u osób młodych i nie łączą się raczej z psychotycznością. Exner jednak, z większym niż 33 procentem minusowych wypowiedzi $S$ zdecydowanie łączy potrzebę interwencji, udzielenia pomocy, zwłaszcza gdy ogólna liczba wypowiedzi „minusowych” jest większa niż trzy [ 6, s. 17-18], a takie wyniki mamy u mężczyzny nr 2.

W sumie możemy powiedzieć, że u badanego $\mathrm{nr}$ 2 procesy poznawcze mogą ulegać dezorganizacji pod wpływem negatywnych emocji (złości), a ponadto, ze względu na swą niekonwencjonalność, nie muszą one „pasować” do ogólnie przyjętych konwencji. W stosunku do mężczyzny nr 1 nie możemy przyjąć takich wniosków; co więcej, jego wypowiedź nr 9 w systemie interpretacyjnym Piotrowskiego należałoby ocenić jako wypowiedź oryginalną. Wydaje się, że mimo „minusowej” wypowiedzi nr 28 można powiedzieć, że reakcje typu S są u tego mężczyzny na ogół adekwatne do bodźców, a nawet bywają celne i mogą być wyrazem niezależnego i twórczego myślenia. Wracając do badanego nr 2 należy w końcu zauważyć, że liczne perseweracje, jakie wystąpiły w jego wypowiedziach świadczą o sztywności zachowań i myślenia ( $u$ badanego $\mathrm{nr}$ 1, perseweracja wystąpiła tylko raz, u badanego nr 2 zaś aż sześciokrotnie).

Podsumowując dotąd opisane dane powiem, że myśli mężczyzny nr 2 nie tylko często były nieadekwatne ale dodatkowo, nierzadko biegły mniej utartym społecznie torem (choć liczba wypowiedzi popularnych względem treści była u obu badanych praktycznie taka sama), a więc jego współbrzmienie myślowe z otoczeniem społecznym mogło nie być dostateczne; co więcej, jego procesy myślowe łatwo ulegały dezorganizacji pod wpływem negatywnych emocji, a reakcje złości, buntu i krytyki, jeśli występowały, mogły być nieadekwatne do sytuacji i nieadaptacyjne. Nieprzystosowanie myślowe nasilała sztywność procesów poznawczych (liczne perseweracje)

Aby w pełni scharakteryzować funkcjonowanie poznawcze obu badanych należy poczynić jeszcze dalsze kroki. Po pierwsze, należy zliczyć liczbę takich interpretacji plam, w których badani kierowali się więcej niż jedną determinantą przy formowaniu jednej wypowiedzi ( Blends); u pierwszego z badanych liczba ta to 6, u drugiego zaś to 5, nie widzimy więc tu znaczniejszych różnic; obaj badani w podobnym stopniu wykorzystywali złożoność prezentowanych im bodźców ( brali pod uwagę nie tylko kształt plam ale i inne ich cechy, np. kolory czy dynamikę). Po wtóre, trzeba zliczyć sumę punktów uzyskaną za „wypowiedzi Z” i porównać ją z estymowanymi wartościami przewidzianymi dla częstości pojawiania się tych wypowiedzi. Pierwszy z badanych wykazał się niższą wartością $\sum \mathrm{Z}$ (45.5) ,i co więcej była ona niższa niż oczekiwana, ale jedynie w nieznaczym stopniu. Drugi badany miał wyższą liczbę $\sum Z$ (72.0), czyli więcej energii wydawał na organizację pola bodźcowego, ale rezultaty jego wysiłku również nie były w pełni efektywne, $\sum Z$ była niższa niż wartość oczekiwana [ 4]. Po trzecie, należy zwrócić uwagę na „Jakość Rozwojową" ( czyli DQ ). Tutaj zaznaczyła się różnica: mimo że obaj badani uzyskali wartościowe sygnatury: DQo oraz DQ+, to badany nr 2 miał jednak dwie wypowiedzi, które otrzymały sygnaturę v: świadczy to o tym, że badany nr 2 czasem zatrzymywał się na ogólnym wrażeniu i nie analizował struktury plamy.

Czyniąc następne podsumowanie powiem, że procesy poznawcze obu badanych, ale szczególnie drugiego, nie były w pełni efektywne w stosunku do wkładanego wysiłku. Ponadto badany nr 2 czasem nie wykorzystywał struktury plamy w swojej interpretacji, co może świadczyć o upraszczaniu poleconego mu zadania.

Aby ocenić zdolność do samokontroli należy wziąć pod uwagę zasoby psychiczne, które są łatwo dostępne i które jednostka może wykorzystywać w codziennym funkcjonowaniu. Przyjmuje się, że o potencjale tym w teście Rorschacha świadczy liczba wypowiedzi determinowanych ruchem ludzkim oraz wypowiedzi determinowanych kolorem (chromatycznym). Liczbę punktów, jaką badana osoba otrzymuje za tego typu wypowiedzi określa się sygnaturą EA (experience actual) [ 4, 5 ]. Uważa się, że przeciętne wartości EA (dla osób dorosłych i dojrzewającej młodzieży) mieszczą się w granicach od 7 do 11 [4]. Mężczyzna nr 1 uzyskał tu 7.5 punktów, zaś mężczyzna nr 2 uzyskał 5.5 punktów. Obaj badani nie mają więc wysokich wyników, ale podczas gdy wynik pierwszego $\mathrm{z}$ nich mieści się $\mathrm{w}$ granicach normy, wynik drugiego jest zbyt niski. Exner uważa, że osoby o niskim EA ulegają permanentnej dezorganizacji pod wpływem zwykłych, nieodłącznych od codziennego życia stresów i są bardziej podatne na zranienie. Ludzie ci lepiej funkcjonują w sytuacjach, które są dobrze ustrukturyzowane i pozbawione wieloznaczności. Wykonywanie testu Rorschacha, w którym należy interpretować niedookreślone plamy, musiało więc być dla drugiego z badanych wysoce stresujące.

Być może dlatego badany nr 2 przyjął postawę unikania, ignorując złożoność prezentowanych mu bodźców. Postawę tę (avoidant style) określa się w teście Rorschacha przede wszystkim poprzez sprawdzenie, czy badany uwzględnia głównie kształt plam a ignoruje inne ich cechy, takie jak np. kolor lub światłocienie. Postawę tę ujmuje się w tzw. L (Lambda). Lambda to stosunek 
liczby wypowiedzi determinowanych samym kształtem plam do wszystkich pozostałych wypowiedzi. Zwykle $\mathrm{L}$ jest mniejsze od 1 . Pierwszy z badanych uzyskał tu wartość 0.43 . Jeśli L jest większe niż 1 , a szczególnie jeśli jest większe niż 1.2, możemy mówić o bardzo nasilonej tendencji do upraszczania. Drugi badany uzyskał tu wynik 1.8, a więc bardzo wysoki. Kierując się szczegółowymi wytycznymi Exnera [4] można przypuszczać, że postawę tę mężczyzna nr 2 utrzymuje także w innych niż badanie psychologiczne sytuacjach życiowych. Styl unikowy można traktować jako wysiłek ukierunkowany na zapanowanie nad złożonymi sytuacjami napotkanymi w życiu i reagowaniu w sposób jak najprostszy, ekonomiczny, negujący skomplikowany charakter bodźców. Czasami taka pośrednia forma kontroli może być efektywna i uwalniać stosującą ją osobę od poczucia przytłoczenia zewnętrzną sytuacją. Tendencja unikowa może jednak nie być skuteczna wówczas, gdy pozostaje ona w konflikcie z koniecznością uwzględniania złożoności danej sytuacji. Michał Stasiakiewicz pisze, że wysoki wynik we wskaźniku L, przy niskim procencie wypowiedzi o dobrym poziomie formy $(\mathrm{X}+\%)$ i niewielkiej liczbie wypowiedzi popularnych, może świadczyć o indywidualistycznym, mało empatycznym sposobie funkcjonowania i tendencji do zachowań konfrontacyjnych [5]. U badanego $\mathrm{nr} 2$ procent wypowiedzi X+ (32) nie był duży, lecz przeciętna liczba wypowiedzi popularnych (5 według norm polskich) była wystarczająca [ 7, s. 79]. Ogólnie biorąc, należy jednak stwierdzić, że badany nr 2 charakteryzował się unikowym stylem reagowania. Zdaję sobie sprawę, że wysoka wartość L jest w pewnym stopniu niespójna z jednoczesnym kilkakrotnym braniem pod uwagę więcej niż jednej determinanty; myślę jednak, że możemy mieć tu do czynienia z dwutorowym reagowaniem: albo „poddaję się" złożoności bodźca albo (częściej) reaguję w skrajnie powściągliwy sposób (biorę pod uwagę tylko i jedynie kształt plamy).

Obaj badani dali stosunkowo niewiele wypowiedzi na tablice wielobarwne w stosunku do liczby wypowiedzi na tablice ciemne. W teście Rorschacha relacja ta ujęta jest we wskaźniku Afr (affective ratio) i interpretowana jako zależność lub brak zależności emocjonalnej od otoczenia społecznego (mężczyzna nr 1 uzyskał Afr = 0.42; mężczyzna nr 2 zaś Afr $=0.47$ ). Myślę, że te wyniki odpowiadają normie i nie można powiedzieć, by reaktywność emocjonalna obu badanych była nadmierna [4].

Kolejny krok to porównanie zasobów psychicznych z tzw. es (experienced stimulation). Porównanie takie daje wgląd w skuteczność radzenia sobie ze stresem a także ocenę, czy stres związany jest z sytuacjami zewnętrznymi ( a więc łatwiejszymi do opanowania, czy też wypływa z wewnętrznych uwarunkowań związanych z głębszymi predyspozycjami, trudniejszymi do przezwyciężenia ). $\mathrm{Na}$ es składają się wypowiedzi determinowane ruchem zwierzęcym, ruchem przedmiotów nieożywionych, barwą achromatyczną i wszystkimi rodzajami światłocienia. Wysokie es wiąże się z impulsywno-lękową regulacją psychiczną i poczuciem permanentnego przeciążenia, chyba że wysokie es zostanie „zrównoważone” przez dostępne i dobrze zorganizowane potencjały psychiczne (EA). Różnica między tymi dwoma zmiennymi mówi o tolerancji na stres i w pewnym sensie jednocześnie o kontroli emocji (różnicę tę oznaczamy literą D). Gdy różnica nie przekracza -2.5 oraz +2.5 możemy mówić o wynikach przeciętnych. Ponieważ mężczyzna nr 1 uzyskał w EA 7.5 punktów a w es 11 punktów, w jego przypadku D będzie wynosiło - 3.5. Mężczyzna $\mathrm{nr} 2$ uzyskał w EA 5.5 punktów a w es 5 punktów, w jego przypadku D będzie wynosiło + 0.5 punktu. W tabeli $\mathrm{nr}$ $10.4 \mathrm{w}$ podręczniku Exnera [4] wyniki te przelicza się według odchylenia standardowego równego 2.5. Wynik badanego nr 1 przekracza więc odchylenie standardowe $\mathrm{w}$ kierunku minusowym (-1), podczas gdy wynik mężczyzny nr 2 pozostaje w normie (0). Można by więc sądzić, że mężczyzna nr 1 słabiej kontroluje swe emocje i łatwiej poddaje się stresowi.

Nie jest to jednak do końca prawdą, jak się bowiem okaże, stres, któremu ulega badany nr 1 ma raczej charakter przejściowy, sytuacyjny a odporność na stres u badanego nr 2 może być przeceniona. Dzieje się tak dlatego, że gdy wyeliminujemy $\mathrm{z}$ es wszystkie prócz jednej sygnatury m i wszystkie prócz jednej sygnatury Y, uzyskamy wówczas wartość Adj es (adjusted es), która będzie oceniona inaczej. Uważa się bowiem, że uwzględnianie ruchu przedmiotów nieożywionych (m) i tzw. rozlanego światłocienia (Y ) łączy się ze stresem uwarunkowanym sytuacyjnie. Wartość Adj es eliminuje więc większość tych sygnatur, które wiążą się ze stresem sytuacyjnym (m, Y). Adj es u pierwszego badanego wyniosło 8, dając tym samym Adj D równe 0.5 , co w tabeli 10.4 [4] odczytuje się jako wartość 0 . U drugiego badanego Adj es wyniosło 4, dając Adj D $=2.5$, co również daje wartość 0 . Możemy więc przyjąć, że obaj mężczyźni (biorąc pod uwagę te właśnie wskaźniki) nie różnią się między sobą istotnie pod względem odporności na stres. Ten brak różnicy nie jest całkiem jednoznaczny, ponieważ Adj es, według Exnera średnio powinno mieścić się w granicach 5 - 9, a więc u mężczyzny nr 2 uzyskana wartość to 2.5, a więc Adj es nie jest w pełni wiarygodne. Dlatego więc za Exnerem można przewidywać, że mężczyzna nr 2 może mieć większe trudności w opanowywaniu stresu niż mężczyzna nr 1 . Mężczyzna nr 1 uzyskał w Adj es 8 punktów, co można traktować jako wynik zbliżający się do wartości optymalnej a jego negatywne emocje należy wiązać raczej ze stresem sytuacyjnym, a nie tym, 
który wynika z głębi psychiki niezależnie od warunków zewnętrznych.

Podsumowując dotychczasowe ustalenia powiem, iż można sądzić, że badany nr 2, dysponował mniejszymi zasobami psychicznymi a podczas badania przyjął wyraźną postawę unikową, co można próbować zrozumieć jako mechanizm obronny przed emocjami, jakie budziły w nim prezentowane mu plamy. Po dokładnej, i przyznaję: żmudnej, ocenie radzenia sobie ze stresem, można powiedzieć, że badany nr 1 doznawał stresu być może silniej, ale radził sobie z nim dostatecznie dobrze, i co ważniejsze, jego stres miał charakter sytuacyjny, natomiast wyniki badanego nr 2, choć nie były w pełni spójne i czytelne, mogą być podstawą do przypuszczeń, że stres którego doznawał wiązał się raczej z wewnętrznymi problemami a nie ze zrozumiałym w pewnym stopniu stresem związanym z samą sytuacją badania.

Przystosowanie społeczne mierzy opracowany przez Exnera Wskaźnik Deficytu Mechanizmów Radzenia (CDI) $[4,5]$. We wskaźniku tym mężczyzna nr 1 uzyskał 2 punkty, zaś mężczyzna nr 2 zaś 4 punkty. Aby uniknąć nadmiernej szczegółowości analizy wyników, nie przetaczam sposobu w jaki oblicza się CDI a zainteresowanego tym czytelnika odsyłam do podręcznika [ 4, 5]. Exner pisze, że jeśli wartość Adj D wynosi 0, a wartość CDI jest niższa niż 4, zdolność badanej osoby do kontroli i tolerancji stresu jest zbliżona do tych zdolności, którymi dysponuje większość ludzi i takie wyniki otrzymał mężczyzna nr 1. Jeśli wartość Adj D odpowiada 0, a wartość CDI wynosi przynajmniej 4, wówczas należy stwierdzić, że organizacja osobowości badanej osoby jest mniej dojrzała niż należałoby oczekiwać. Osoba taka łatwiej ulega zranieniu i nie radzi sobie ze stresami codziennego życia, zwłaszcza gdy dotyczą one relacji interpersonalnych, a jej zdolność do samokontroli jest mniejsza niż przeciętna [4]. Widzimy więc, że badany nr 1 potrafi kontrolować swe emocje i tolerować stres w stopniu wystarczającym do tego, by radzić sobie w życiu, a jeśli przeżywa stres, jest on związany raczej z czynnikami sytuacyjnymi ( es=11). Badany nr 2 może mieć pewne problemy adaptacyjne, prawdopodobnie nie radzi sobie z negatywnymi emocjami, a przeżywany przez niego stres pochodzi raczej z wnętrza psychiki, a więc ma głębsze źródła niż stres sytuacyjny.

Co więcej, badany nr 2 uzyskał wysoki wynik we wskaźniku izolacji społecznej (II). Ten opracowany przez Exnera wskaźnik oblicza się na podstawie częstości pojawiania się treści związanych ze środowiskiem naturalnym ( uwzględnia się tu kategorie: botanika- Bt, krajobraz- Ls, geografia- Ge, natura- $\mathrm{Na}$, chmury- $\mathrm{Cl}$ ). Dodajemy wszystkie istotne dla tego wskaźnika treści i dzielimy ich sumę przez liczbę wszystkich wypowiedzi uzyskanych w całym badaniu. Wartości uzyskane dla kategorii „natura” i „chmury” należy podwoić, ze względu na to, że wyjaśniają one największą część wariancji. Jeśli pojawi się w wypowiedzi kategoria $\mathrm{Na}$, jak już wspominałam, nie uwzględniamy już żadnej z pozostałych kategorii dla tej właśnie wypowiedzi $\mathrm{z}$ wyjątkiem kategorii $\mathrm{Cl}$ [4, 5, 8, 9, 10 ]. Badany $\mathrm{nr} 1$ we wskaźniku izolacji uzyskał wynik 0.07 a więc bardzo niski, natomiast wynik badanego nr 2 wyniósł 0.39 a więc był bardzo wysoki. Brak dostatecznego poczucia zakorzenienia $\mathrm{w}$ środowisku społecznym może nasilać trudności emocjonalne mężczyzny $\mathrm{nr} 2$.

Następne podsumowanie to stwierdzenie, że podczas gdy możemy powiedzieć, żę mężczyzna nr 1 wykazał się dobrym dostosowaniem społecznym i poczuciem zakorzenienia w środowisku, mężczyzna nr 2, jak można przypuszczać, doznaje trudności adaptacyjnych i silnego poczucia osamotnienia. Na korzyść mężczyzny $\mathrm{nr} 1$ pracuje ponadto typ temperamentu, mężczyzna nr 2 może mieć pod tym względem dodatkowe trudności związane z większą niestabilnością postaw ( problem temperamentu omówię dalej). W sumie jednak należy przyznać, że mimo pewnych problemów emocjonalnych u mężczyzny nr 2 , obaj badani to osoby z dobrze uspołecznioną sferą emocjonalną.

Test Rorschacha jest źródłem interesujących danych dotyczących temperamentu, który nazywa się tu typem przeżywania. Zdecydowanie ekstratensywny (pervasive) typ przeżywania mężczyzny $\mathrm{nr} 1 \mathrm{z}$ pewnością ułatwia mu efektywne funkcjonowanie i podejmowanie decyzji. Aby określić typ przeżywania porównuje się liczbę wypowiedzi $\mathrm{M}$ w relacji do $\sum \mathrm{C}$, dzieląc większą wartość (u badanego nr 15.5) przez wartość mniejszą (u badanego nr 2, 2). Gdy wynik jest większy od 2.5 możemy mówić o dominującym stylu przeżywania w tym znaczeniu, że styl przeżywania zaznacza się $\mathrm{w}$ sposób wyrazisty. U badanego $\mathrm{nr} 1$, ze względu na przewagę uwzględniania koloru, styl ten jest właśnie ekstratensywny (Eb Per = 2.75)[5]. U mężczyzny nr 2, relacja $M: \sum C$ wyniosła 3:2.5. Według Exnera nie można w tym wypadku obliczyć EB Per z powodu zbyt wysokiej wartości L [4]. Należy więc przyjąć, że mężczyzna drugi reprezentuje styl ambitendentny. Styl taki odznacza się zmiennością zachowań i brakiem konsekwencji. Oba biegunowe style przeżywania - styl ekstratensywny i introwertywny, jeśli zaznaczają się w sposób zdecydowany - mają podobną siłę, ułatwiają bowiem podejmowanie decyzji i konsekwentne dążenie w określonym kierunku. Styl ambitendentnyl natomiast nie jest tak efektywny w przezwyciężaniu trudności sytuacyjnych [5, s. 138].

Należy zauważyć, że u obu badanych nie wystąpiły wypowiedzi determinowane samym kolorem (C), które świadczyłyby o bardzo emocjonalnym, impulsywnym zachowaniu. Przewagę uwzględniania kształtu nad kolorem interpretuje się jako uspołecznienie sfery 
emocjonalnej. Emocje mężczyzny drugiego były bardzo dobrze kontrolowane intelektem

$(\mathrm{FC}:(\mathrm{CF}+\mathrm{C})=2.5$

:0), u mężczyzny pierwszego zaś podobna relacja to 2.5 : 3 . Grzywak -Kaczyńska ten ostatni układ relacji wypowiedzi determinowanych kształtem i kolorem uważa za bardzo korzystny wychodząc z założenia, że emocje, gdy nie są zbyt silne ale jednocześnie gdy zaznaczają się wystarczająco dobitnie, ułatwiają przystosowanie [11].

Ostatni aspekt wypowiedzi, który należy wziąć przy ocenie tego, jak interpretować reakcje $S$ to dokładniejsza analiza tych cech wypowiedzi, które mogą łączyć się z jakością relacji interpersonalnych oraz z obrazem własnej osoby. Przede wszystkim należy zauważyć, że obaj badani mówili o ludziach dostatecznie często a procent tych wypowiedzi nie był zbyt duży (20\% i 22\%). Świadczy to o zainteresowaniu ludźmi bez zabarwienia lękowego. Jak już pisałam, Exner ocenia wypowiedzi mówiące o ludziach pod względem treści oraz pod względem cech formalnych, opatrując je sygnaturą GHR lub PHR. Jak wspominałam, analizując te właśnie reakcje obu badanych kierowałam się zasadami opracowanymi przez Exnera oraz licznymi przykładami, jakie przytacza w swoim podręczniku [4]. Trudna do oceny była wypowiedź nr 30 drugiego mężczyzny; ruch kooperacyjny przemawia tu za GHR, ale zaliczenie tej wypowiedzi do determinanty $\mathrm{M}$ bez formy, każe zaliczyć tę wypowiedź do kategorii PHR. Mężczyzna nr 1 podał trzy wypowiedzi zaklasyfikowane do GHR oraz trzy wypowiedzi zaklasyfikowane do PHR. U mężczyzny nr 2 wystąpiły cztery wypowiedzi GHR oraz cztery wypowiedzi PHR. W mojej ocenie różnice między badanymi pod tym względem nie są znaczące. Ważniejsze jest jednak to, że obaj badani podali poprawną i w typowy sposób sformułowaną wypowiedź M na tablicę III, co świadczy o braku naprawdę poważnych problemów związanych z relacjami z innymi ludźmi, zwłaszcza z osobami znaczącymi. Badany nr 1 podał jedną wypowiedź M o nieadekwatnej do bodźca formie. Tego typu reakcja zawsze „liczy się” w analizie wypowiedzi uzyskiwanych w teście Rorschacha, ponieważ wszelkie występujące tu nieprawidłowości nierzadko pojawiają się u osób w różny sposób zaburzonych, choć oczywiście jedna tego typu reakcja nie może mieć decydującego znaczenia i nie jest niespotykana u większości badanych. Badany nr 2 podał dwie wypowiedzi tego typu, co już nie jest korzystnym faktem. Wszystkie trzy reakcje $\mathrm{M}-\mathrm{u}$ obu badanych pojawiły się na tablicę $\mathrm{X}$, a więc „emocjonalną” (wielobarwną). Wypowiedź mężczyzny $\mathrm{nr} 1$, mimo że nieadekwatna w stosunku do kształtu plamy, pojawia się wśród badanych dość często. Możemy więc metaforycznie powiedzieć, że podążył on fałszywą, ale nie nazbyt nietypową ścieżką. Wypowiedzi drugiego badanego (nr 30 i nr 31) były natomiast nie tylko błędne ale i niekonwencjonalne. W wypowiedzi nr 31 ludzie widziani po bokach plamy jako siedzący w ławkach to postaci spostrzeżone zupełnie nieadekwatnie, spostrzeżenie w środku plamy idących ludzi też nie jest poprawne. Niebieskie plamy w środku tablicy, spostrzegane jako postacie ludzkie, w podręczniku Exnera oceniane są jako interpretowane właściwie, ale w odwróconej pozycji tablicy, a nie jak to miało miejsce w przypadku badanego nr 2, w pozycji wyjściowej; można by się tu zastanawiać nad przyjęciem unikatowego poziomu formy dla tych postaci, ale zdecydowałam się na ogólną, negatywną ocenę formy dla całej wypowiedzi.

Możemy powiedzieć, że mężczyzna nr 2 miał więcej trudności w poprawnym widzeniu postaci ludzkich, a szczególnie postaci ludzkich w ruchu. Spostrzeganie ludzi w ruchu teoretycy testu traktują jako pewien potencjał, który możemy wykorzystywać w kształtowaniu naszych relacji społecznych. Potencjał ten wiąże się z rolą prototypową, ważnym aspektem osobowości; rola ta jest sposobem „rzutowania” samego siebie w przyszłość, projektowania swego życia według własnych standardów i doświadczeń emocjonalnych z dzieciństwa [ 3, 12 ]. Widzimy więc, że mimo poprawnej reakcji tego badanego na tablicę III, nie jest on wolny od pewnych trudności w relacji do innych ludzi. Co więcej, zauważmy, że postaci ludzkie widziane $\mathrm{w}$ plamach $\mathrm{w}$ połowie przypadków miały zły poziom formy, a więc możemy powiedzieć, że jakieś negatywne emocje przeszkadzały badanemu w efektywnym funkcjonowaniu w środowisku społecznym.

Obaj badani ani razu nie kierowali się tym rodzajem światłocienia, który łączy się z wrażeniami powierzchni (T). Ta sytuacja upoważnia do sprawdzenia, jakie wyniki uzyskają oni we Wskaźniku Nadmiernej Czujności (Hypervigilance Index - HVI). Pierwszy badany uzyskując 3 punkty zmieścił się ze swoim wynikiem w granicach normy, drugi natomiast uzyskując 4 punkty ujawnił tendencję do pozostawania w stanie nadmiernej czujności, wynikającej z lęku i negatywnej antycypacji i zdarzeń. Osoby z taką postawą do świata unikają bliskich kontaktów z innymi z powodu braku ufności i z obawy przed nadmierną ingerencją innych ludzi w swoją osobistą przestrzeń [5]. Czytelników zainteresowanych obliczeniem wartości HVI odsyłam do podręczników [ 4, 5 ].

Podsumowując należy podkreślić, że podczas gdy mężczyzna nr 1 nie miał trudności w relacjach z innymi ludźmi, badany nr 2 spostrzegał ludzi nieadekwatnie, a negatywne emocje utrudniały mu utrzymanie pozytywnych relacji z nimi, można nadto przypuszczać, że bywa on nieufny i podatny na zranienie: wykazał skłonność do tego, by spodziewać się niekorzystnego obrotu spraw a także by przewidywać, że zostanie skrzywdzony przez innych ludzi.

Zaznaczyła się znacząca różnica między obu 
badanymi w samoocenie. Wykorzystałam tu opracowany przez Exnera Wskaźnik Egocentryczności (I Ego). Wskaźnik ten, którego trafność często mnie zawodziła, tym razem okazał się pomocny i spójny z ogólnym obrazem psychiki obu mężczyzn. I Ego dotyczy tych wypowiedzi, w których występują pary, tzn. widziane są dwa takie same obiekty, a także wypowiedzi mówiące o odbiciach. Aby uzyskać wartość wskaźnika, należy do potrojonej sumy wypowiedzi mówiących o odbiciu dodać sumę wypowiedzi mówiących o parach i uzyskany wynik podzielić przez liczbę wszystkich wypowiedzi uzyskanych w całym badaniu. Uważa się, że wskaźnik egocentryczności odzwierciedla nie tylko stopień skoncentrowania się na sobie, ale także odnosi się do samooceny. Jeśli uzyskany wynik jest wyższy niż wartość przeciętna, świadczy to o nadmiernym zaabsorbowaniu własną osobą. Kluczową rolę odgrywa liczba „odbić”; tego typu wypowiedzi interpretowane są bowiem jako wskazujące na tendencje narcystyczne. Jeśli pomimo wysokiej wartości indeksu nie ma wypowiedzi „z odbiciem", można podejrzewać, że samoocena badanej osoby nie jest wysoka a skoncentrowanie się na własnej osobie może wynikać $\mathrm{z}$ poczucia trudności $\mathrm{w}$ relacji do samego siebie. Jeśli wartość indeksu jest niższa niż przeciętna, a zwłaszcza gdy nie ma odbić, należy liczyć się z deprecjacją własnej osoby [4, 5]. Według Exnera dla zdrowych osób średnia wartość indeksu mieści się między 0.33 a 0.45 ; młode osoby (od szesnastego roku życia $\mathrm{w}$ dół) mają wyższe wskaźniki. Badany nr 1 uzyskał I Ego=0.37, więc wynik jego mieści się w normie, zwłaszcza że aż dwa razy mówił o odbiciach. Badany nr 2 uzyskał w I Ego bardzo niski wynik - 0.03; nie wystąpiła ponadto u niego żadna wy powiedź mówiąca o odbiciach. Należy więc podkreślić, że ten badany nie ma dobrego mniemania o samym sobie, a negatywna samoocena może motywować go do przyjmowania postawy buntu i sprzeciwiania się lub wycofywania jako mechanizmów obronnych.

U badanego nr 1 pojawiła się pojedyncza sygnatura FD, co świadczy o zdrowej tendencji do samorefleksji [ 4, 5]. U badanego nr 2 FD wystąpiło aż trzykrotnie. Mimo że sygnatura ta częściej występuje u osób dojrzewających, aż trzy sygnatury FD mogą świadczyć o tym, że badany nadmiernie oddaje się introspekcji a także że łatwo ulega depresyjnym nastrojom.

Na koniec spójrzmy na treść wybranych wypowiedzi. Mężczyzna nr 1 zobaczył na Tablicy II tańczące słonie. Taniec jest ruchem typowym dla ludzi, a przypisanie go zwierzętom, w teście Rorschacha interpretuje się jako reakcję typową dla idealistów rozczarowanych nieuczciwością i hipokryzją otoczenia; rozczarowanie to może prowadzić do nastrojów depresyjnych lub do cynizmu i oportunizmu [3]. Możemy więc powiedzieć, że badany nr 1 przeżywa jakieś trudności związane z oceną postępowania ludzi, wobec której nie potrafi zająć w pełni dojrzałego stanowiska. Gdy uwzględnimy wszystkie wyniki jakie uzyskał ( adekwatne spostrzeganie innych ludzi, uspołeczniona sfera emocjonalna, pewność siebie i pozytywny obraz własnej osoby, zdecydowanie ekstratensywny styl przeżywania ułatwiający podejmowanie decyzji) nie można powiedzieć, by były to trudności poważne. Mimo to zauważmy, że „złą” wypowiedź o treści „człowiek” omawiany tu badany podał na ostatnią tablicę testu, tak jakby nie potrafił zapanować nad skumulowanymi negatywnymi emocjami. Uwzględnienie białego tła w tej wypowiedzi wprowadziło do niej element krytyki, uwzględnienie kolorów dodatkowo zabarwiło ją emocją a dynamiczne ujęcie podkreśliło jej znaczenie dla badanego. Określenie „dziwoląg” spotęgowało ekspresję wypowiedzi. Myślę, że wypowiedź tę można uznać za wypowiedź-klucz, która symbolicznie wyraża podstawowy problem badanego: problem nieuczciwych zachowań innych ludzi i frustracja związana z negatywną ich oceną. Problem ten był już zasygnalizowany przy spostrzeżeniu tańczących słoni. Wypowiedź „tańczące slonie” interpretuję jako wyraz rozczarowania i krytycznego stosunku do innych ludzi.

Myślę, że także inna wypowiedź, a mianowicie ta mówiąca o gwieździe na maszcie, może być traktowana jako wypowiedź-klucz. Można zapytać, czy gwiazda to nie symbol przewodniczki w życiowej podróży. Pewna nielogiczność w powiązaniu statku i gwiazdy ze względu na małe prawdopodobieństwo tego powiązania w realnym życiu, potwierdza emocjonalne nasycenie tego obrazu. James P. Choca i Edward D. Rossini [13] wprowadzają do badania testem plam fazę uzupełniającą ( Follow Up Phase), w której prosi się badaną osobę o dodatkowe informacje na temat podanych wypowiedzi, pyta o ich uzasadnienie i o własną interpretację. Myślę, że wszystkie trzy wypowiedzi, o których tu pisałam byłyby wdzięcznym tematem do poruszenia w fazie Follow Up.

U mężczyzny $\mathrm{nr} 2$ ważnymi wypowiedziami dotyczącymi człowieka były dwie ostatnie wypowiedzi podane na Tablicę X. Tablica $X$ należy do jednej $\mathrm{Z}$ najtrudniejszych do interpretacji ze względu na jej rozczłonkowanie oraz ze względu na poczucie chaosu, które wzbudza oraz trudność jaką sprawia, gdy pragnie się nadać jej syntetyczną interpretację. Badany nr 2 starał się ująć całość, udało mu się to w wypowiedzi 29 ale zawiodło w dwu następnych interpretacjach. Mówiąc o balu wykorzystał białe tło i kolory, co podniosło emocjonalny poziom tej wypowiedzi. Nie było tu łatwo zdecydować, jaki poziom DQ nadać tej wypowiedzi. Sam badany mówił o ogólnym wrażeniu (wówczas byłaby tu właściwa sygnatura Wv), a jednak wskazał na schody, które zobaczył w różowych plamach i które nadały spostrzeżeniu pewne ustrukturyzowanie i z tego 
powodu zdecydowałam się na nadanie tej wypowiedzi sygnatury WS+. Postacie tańczących ludzi nie zostały jednak zidentyfikowane, wrażenie ruchu było wrażeniem ogólnym i z tego powodu za determinantę przyjęłam tu M bez formy. Następna i ostatnia wypowiedź mówiła o wnętrzu kościoła z siedzącymi w ławkach ludźmi oraz ludźmi idącymi środkiem nawy. Wypowiedź ta w mojej ocenie nie odpowiada plamie pod względem formy. Muszę przyznać, że obie omawiane tu wypowiedzi nie są łatwe do zasygnowania. Mimo negatywnej oceny co do poziomu formy, należy przyznać, że obie były naszkicowane z polotem. To, co ważne to ujęcie ludzi jako niezróżnicowanej masy, tłumu, bez zidentyfikowanych pojedynczych postaci. Badany był narratorem, który pozostawał na zewnątrz sceny, był outsiderem, nie należał do przedstawionych sytuacji i patrzył na nie z perspektywy lotu ptaka. Omawiane wypowiedzi korespondują z wypowiedziami dotyczącymi natury, krajobrazu, roślin, czyli z tymi wypowiedziami, na podstawie których oblicza się indeks izolacji, są pewnym kontrapunktem: i świat natury i świat społeczny w doświadczeniu badanego mówią mu o jego własnej izolacji i osamotnieniu. Dwie ostatnie wypowiedzi badanego można potraktować jako wypowiedzi- klucze i poprosić o ich zinterpretowanie w fazie Follow Up. Ciekawe, że obaj badani na Tablicę X podali interpretacje, które stanowią podsumowanie najistotniejszego dla każdego $\mathrm{z}$ nich problemu, problemu wokół którego można opisać całość badania. Można mieć wrażenie, że kontakt z plamami zapoczątkował u obu badanych pracę nad wglądem we własną psychikę i praca ta zaowocowała stworzeniem odpowiednich obrazów.

\section{Dyskusja}

Przypatrzmy się jeszcze raz uzyskanym wynikom. Na pierwszy „rzut oka” wypowiedzi badanych nie były dramatycznie różne. Podali niemal identyczną liczbę wypowiedzi i zbliżoną liczbę interpretacji białego tła, a te ostatnie miały podobny rozkład, jeśli weźmie się pod uwagę pojawianie się ich na kolejne tablice testu. Nie pojawiły się wypowiedzi wyraźnie patologiczne, ujmowane najczęściej w niektórych tzw. sygnaturach specjalnych. Sfera emocjonalna u obu mężczyzn okazała się dostatecznie uspołeczniona; poprawnie zareagowali też na tablicę III, widząc na niej dynamicznie ujęte postaci ludzkie. Ta ostatnia reakcja wyklucza głębokie nieprawidłowości w ukształtowaniu roli prototypowej. Rola prototypowa ułatwia podstawową stabilizację relacji jednostki z otoczeniem społecznym i ułatwia jej realizację celów życiowych w zgodzie z własną koncepcją siebie i świata.

A jednak, dokładna analiza wypowiedzi ukazała różnice na tyle istotne, że pozwoliły one na spojrzenie na badanego nr 1 jako na osobę dobrze przystosowaną, a na badanego nr 2 jako na osobę potrzebującą intensywnej pomocy. Okazało się też, wypowiedzi S u badanych miały różne znaczenie psychologiczne.

W odniesieniu do mężczyzny $\mathrm{nr}$ 1, możemy mówić zarówno o współdźwięczeniu intelektualnym wyrażającym się w podążaniu podobnymi torami myślenia do tych cechujących ogół ludzi, jak i o zdolności do sądów oryginalnych, twórczych. Dobre radzenie sobie ze stresem i zdecydowanie ekstratensywny typ przeżywania świata, ułatwia temu badanemu podejmowanie decyzji i pewną jednolitość postaw. Najważniejszym atutem badanego jest pewność siebie płynąca z pozytywnej samooceny. Można przyjąć, że krytyczny stosunek do otoczenia, który jest typową postawą mężczyzny nr 1 jako „osoby S”, przynajmniej niekiedy bywa konstruktywny i twórczy. Można też przypuścić, że jeśli wyraża on swoją irytację i złość czyni to prawdopodobnie w sposób mieszczący się w granicach akceptowanych społecznie konwencji. Niezależność myślenia i krytycyzm badanego powinien przysparzać mu szacunku i podnosić prestiż. Oczywiście nie można wykluczyć pewnych napięć w relacjach $\mathrm{z}$ innymi ludźmi, ale mężczyzna nr 1 , dobrze radzi sobie ze stresem. Całość badania pozwala przyjąć, że jego krytyczna postawa wynika z idealistycznej wizji świata i rozczarowania ludźmi, którzy nie zawsze postępują szlachetnie.

W odniesieniu do badanego $\mathrm{nr} 2$ można powiedzieć, że jego wypowiedzi S nie świadczą o tym, by trafnie oceniał innych i poddawał ich celnej krytyce, ale raczej, że wypowiedzi te są wyrazem zgeneralizowanej postawy opozycyjności i negatywizmu. Badany $\mathrm{nr} 2$ nie zawsze obiektywnie i adekwatnie ocenia problemy i sytuacje życiowe, a jego myśli mogą zbyt często podążać mniej utartymi szlakami i nie współbrzmieć z otoczeniem. Ponadto, jego procesy poznawcze łatwo mogą ulegać dezorganizacji pod wpływem silnych negatywnych emocji. Świat dla mężczyzny nr 2 nie jest wystarczająco zrozumiały a jego własne zachowania z kolei nie zawsze są dostatecznie czytelne i zgodne z oczekiwaniami otoczenia. Wszystko to może nasilać poczucie nieufności i lękowego wypatrywania przyszłych niepowodzeń i krzywd. Samoocena tego badanego jest zdecydowanie zaniżona a dodatkowo ambitendentny styl przeżywania utrudnia mu podejmowanie decyzji i utrzymanie stabilnych postaw wobec problemów i sytuacji życiowych. Co więcej, nie potrafi on efektywnie radzić sobie ze stresem. Jako mechanizmy obronne stosuje nieuprawnione upraszczanie świata, wycofanie i unikanie sytuacji zbyt skomplikowanych i trudnych ze względu na ich niesformalizowanie. Wszystko to powoduje, że mężczyzna ten doznaje dotkliwego poczucia osamotnienia i wyobcowania. Można powiedzieć, że zarówno w sferze 
poznawczej jak i emocjonalnej funkcjonuje on jakby na marginesie, bez poczucia zakorzenienia w środowisku i zbyt intensywnie koncentruje się na rozpamiętywaniu własnych niepowodzeń $\mathrm{z}$ przeszłości oraz tych, które zaistnieją w przyszłości. Można przypuszczać, że emocjonalne problemy tego badanego mają swe źródło w dzieciństwie i w pewnych niedostatkach w ukształtowaniu roli prototy powej.

\section{Wnioski}

Celem, jaki sobie postawiłam było ukazanie na dwu konkretnych przykładach, jak podobna liczba interpretacji białego tła podana w tekście Rorschacha może łączyć się z innymi cechami psychicznymi badanych osób. Można to wykazać w kontekście całości wyników. Pokazałam, że cechy związane $\mathrm{z}$ wypowiedziami $\mathrm{S}$ u badanego $\mathrm{nr}$ 1 nie przeszkadzały mu $\mathrm{w}$ dobrym przystosowaniu, a przeciwnie, mogły spełniać korzystną rolę. Wypowiedzi $\mathrm{S}$ badanego $\mathrm{nr} 2$ wynikały $\mathrm{z}$ jego nieprzystosowania i mogły być pewnym mechanizmem obronnym, służącym podniesieniu jego samooceny i rozładowaniu negatywnych emocji. Potwierdziłam stanowisko Fondy, cytowane we Wstępie, który twierdzi, że cechy związane z wypowiedziami S u osób dojrzałych wykorzystywane są $\mathrm{w}$ produktywny sposób, a u osób z trudnościami emocjonalnymi mogą być źródłem dodatkowego obciążenia.

W końcu pragnę podkreślić korzyści, jakie płyną $\mathrm{z}$ podobnych analiz mimo tego, że są one tak bardzo żmudne i pracochłonne. Po pierwsze, psycholog nie operuje „abstrakcyjnymi” wymiarami osobowości lecz ma okazję słuchać, co mówi do niego badana osoba, mając jednocześnie wiedzę jakie psychologiczne znaczenia mogą kryć się za jej wypowiedziami. Po wtóre, badany ma okazję, najczęściej wykorzystywaną w sposób nieświadomy, by samemu wskazywać osobie badającej, co jest dla niego ważne. Co więcej, opracowane przez Exnera indeksy i wskaźniki czynią z testu Rorschacha narzędzie w dużym stopniu zobiektywizowane, pozwalające na pewien pomiar różnych stanów psychicznych i uzasadnienie sądów o badanych osobach. Ważne jest to, że wypowiedzi badanych mogą stać się materiałem do rozmowy z nimi a rozmowa ta nie powinna być odbierana jako przykra ingerencja w ich sprawy; psycholog bowiem zwraca się do badanych w ich własnych słowach i powołuje się na stworzone przez nich obrazy. Możemy metaforycznie powiedzieć, że badany darowuje badającemu „kawałek swojej duszy" ujętej w słowa i obrazy.

\section{Conflict of interest}

The author has declared no conflict of interest.

\section{References:}

1. Fonda ChP. The white-space response. In: Rickers-Ovsiankina MA, editor, Rorschach psychology. Huntington, NY: Robert E. Krieger Publishing Company. 1977; 113-156.

2. Hunca-Bednarska A. Nieco inaczej o teście Hermanna Rorschacha. Eseje. Lublin; Wydawnictwo KUL: 2013.

3. Piotrowski Z. Perceptanalysis. New York, Philadelphia: Exlibris: 1979.

4. Exner JE. The Rorschach. A comprehensive system. Haboken, NJ: John Wiley \& Sons: 2003.

5. Stasiakiewicz M. Test Rorschacha. Warsaw: Wydawnictwo Naukowe Scholar: 2004.

6. Exner JE. The Rorschach. A comprehensive system. Vol. 2: Interpretation. New York, Chichester, Brisbane, Toronto, Singapore: John Wiley \& Sons: 1991.

7. Grzywak-Kaczyńska M. Podręcznik do metody Rorschacha. Third edition. Edited by Maria Braun-Gałkowska. Lublin: Wydawnictwo KUL: 2006.

8. Hunca-Bednarska A. Chmura, kamień i woda. Bad. nad Schizofrenią, 2005; 6: 352-365.

9. Hunca-Bednarska A. Zastosowanie J. E. Exnera "indeksu izolacji" do diagnozy schizofrenii. Roczniki Psychologiczne, 2007; 10: 113-132.

10. Hunca-Bednarska A. Poczucie wyobcowania u rodziców osób chorych na schizofrenię paranoidalną. Roczniki Psychologiczne, 2008; 11: 77-94.

11. Grzywak-Kaczyńska M. Metoda Rorschacha. Warsaw: PZWL: 1967.

12. Hunca-Bednarska A. Movement responses in the Rorschach test. Part 1: Testing healthy and schizophrenic individuals. Curr Prob Psychiatry. 2019; 20: 75-101.

13. Choca JP, Rossini ED. Assessment using the Rorschach Inkblot Test. Washington DC, US: American Psychological Association:n 2018.

\section{Corresponding author}

Anna Hunca Bednarska

Stowarzyszenie MONAR

Poradnia Profilaktyki, Leczenia

i Terapii Uzależnień w Lublinie

20-214 Lublin, ul. Montażowa 15

Otrzymano: 22.09 .2020

Zrecenzowano: 26.11 .2020

Przyjęto do druku: 22.02.2021 